\title{
Las cofradías españolas en la Edad Moderna desde una óptica social. Tres décadas de avance historiográfico
}

The Spanish brotherhoods during the Modern Age from a social point of view. Three decades of historiographic progress

Inmaculada Arias de Saavedra Alías Miguel Luis López-Guadalupe Muñoz

Universidad de Granada

CESXVIII, núm. 27 (2017), págs. 11-50.

DOI: https://doi.org/10.17811/cesxviii.27.2017.11-50

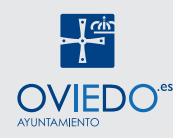




\section{RESUMEN}

No hay fenómeno asociativo más extendido en la España del Antiguo Régimen que las cofradías y hermandades. En consecuencia, su dimensión social ha merecido el análisis histórico en las últimas décadas, incidiendo en aspectos esenciales de su naturaleza: la solidaridad grupal y el mutualismo que despliegan, y el culto público y la multiplicación de fiestas que fomentan. Todo ello desde un indudable afán de autonomía difícil de mantener. A falta de obras de conjunto, la bibliografía es hoy muy abundante y a la vez dispersa. Esa realidad social y la actuación de la autoridad real y eclesiástica sobre el ámbito cofrade se analizan en este artículo, evidenciando los avances en el conocimiento, así como los aspectos que merecen una mayor actividad investigadora.

Palabras clave

Cofradía, Hermandad, Religiosidad, Fiesta, Mutualismo, Iglesia, Regalismo.

\section{ABSTRACT}

No associative phenomenon was more extended during the Ancient Regime in Spain than the brotherhoods. As a consequence, its social dimension deserves the historical analysis it has received these last decades, focusing on the essential aspects of their nature: the group solidarity and the mutual support they demonstrated, the public worship and the numerous festivities that these associations promoted. All these, from an unquestionable eagerness for autonomy that was difficult to maintain. Although there is a lack of complete, cohesive works, nowadays the bibliography on confraternities and brotherhoods can be described as abundant and at the same time scattered. This social reality and the intervention from the royal and ecclesiastical authority on the brotherhood sphere, is analyzed during this particular article, evidencing the advances in knowledge as well as the aspects that deserve a greater research activity.

KeY Words

Brotherhood, Confraternity, Religiousness, Festivity, Mutuality, Church, Regalism.

Recibido: 5 de julio de 2017. Aceptado: 30 de julio de 2017.

Estudio realizado en el marco del Proyecto HAR2014-52850-C3-2P del Ministerio de Economía y Competitividad. 
Los estudios sobre hermandades y cofradías en la España del Antiguo Régimen han experimentado una auténtica eclosión en los últimos años, si bien existe una bibliografía anterior, clásica, en muchos casos erudita, excesivamente descriptiva y anecdótica. Por desgracia estas deficiencias perviven en buena parte de las publicaciones recientemente aparecidas. Pero desde hace alrededor de treinta años vienen desarrollándose corrientes de análisis más solventes y rigurosas, integrando el amplio movimiento cofrade en las líneas maestras de la historia social, de las mentalidades, de la vida cotidiana, en definitiva, en la nueva historia cultural. Abrirse paso en el amplio elenco de monografías, artículos de revista, aportaciones a congresos, e incluso reuniones científicas centradas en esta temática, no es tarea fácil. La pretensión de este trabajo es ofrecer una guía a los estudiosos del tema, e incluso al lector interesado en temas cofrades ${ }^{1}$. Partiendo de grandes áreas temáticas, variadas como multiforme es el fenómeno cofrade, se ofrecen algunas reflexiones apoyadas en la bibliografía más relevante. La cantidad ingente de títulos obliga a ser selectivos, hemos descartado visiones excesivamente localistas e incluso publicitarias, estudios sobre cofradías concretas y ensayos anecdóticos, para centrarnos en aquellos trabajos que pensamos merecen consideración científica. Por razones de volumen y de especialización propia, se han primado los estudios de ámbito andaluz. No hemos pretendido ser exhaustivos, pero sí citar aquellos trabajos que nos parecen más relevantes.

\section{Orígenes e implantación de las cofradías}

Durante el Antiguo Régimen las cofradías fueron, tanto en Europa como en España ${ }^{2}$, una de las expresiones más importantes de la religiosidad popu-

1 Han pasado casi dos décadas de la reflexión historiográfica de Jesús M. ${ }^{a}$ Usunáriz GarayoA, «Los estudios sobre religiosidad popular en la España Moderna en los últimos veinticinco años», Zainak, 18 (1999), págs. 17-43.

2 A nivel general el fenómeno cofrade ha despertado interés en el ámbito europeo, y particularmente en Francia e Italia: Maurice Agulhon, La sociabilité méridionale. Confréries et associations dans la vie collective en Provence orientale à la fin du XVIIIe siècle, Aix-en-Provence, Presses Universitaires, 1966; Giancarlo 
lar³. Estas comunidades de laicos en el seno de la Iglesia católica constituían el cauce asociativo más generalizado de la época. Diversos autores se han planteado el origen de estas asociaciones y casi todos coinciden en fijarlo en la baja Edad Media ${ }^{4}$. A partir del siglo XvI se multiplicaron por doquier, no sólo a través de la creación de nuevas fundaciones, sino también por medio de la restauración de antiguas hermandades de origen medieval ${ }^{5}$, en un preludio de la gran eclosión cofradiera barroca, que se extendería a lo largo del siguiente siglo y tendría su punto culminante en la primera mitad del siglo XVIII, etapa en la que el ritmo fundacional de cofradías alcanzó su mayor velocidad.

A finales del Antiguo Régimen las cofradías estaban bien implantadas en España, tanto en el mundo rural como en las ciudades, aunque era en estas últimas donde tenían mayor presencia. Hace ya casi dos décadas evaluamos su implantación en las principales ciudades del país, relacionando el número de cofradías con la población de estas ciudades, al tiempo que analizábamos aspectos trascendentales como sus advocaciones o ubicación en diferentes sedes $^{6}$. Los estudios sobre la realidad cofrade en ciudades concretas son bastante

Angelozzi, Le confraternite laicali. Un'esperienza cristiana tra medioevo e eta moderna, Brescia, Queriniana, 1978; Marie-Helène Froeschlé-Chopard, La religión populaire en Provence orientale au XVIII siécle, Paris, Beauchesne, 1980; Luigi Fiorani (coord.), Le confraternite romane. Esperienza religiosa, societá, commitenza artistica, Roma, Edizioni di Storia e Letteratura, 1984; Christopher F. BLACK, Italian Confraternities in the Sixteenth Century, Cambridge, Cambridge University Press, 1989. Y más recientemente, reflexiones como la de Liane Bertoldi Lenoci, «La religiosidad popular manifestada en las cofradías», en Francisco J. Campos y Fernández de Sevilla (dir.), Religiosidad popular en España, Madrid, Instituto Escurialense de Investigaciones Históricas y Artísticas, 1997, vol. I, págs. 961- 972.

3 Desde el punto de vista histórico ofrece una aproximación de conjunto la obra de William A. ChrisTIAN, Religiosidad local en la España de Felipe II, Madrid, Nerea, 1991. Una visión general anterior al proceso ilustrado en Inmaculada Arias de SaAvedra alías y Miguel L. López-Guadalupe Muñoz, «Auge y control de la religiosidad popular andaluza en la España de la Contrarreforma», en José Martínez Millán (dir.), Felipe II (1527-1598). Europa y la Monarquía Católica, Madrid, Universidad Autónoma de Madrid, 1998, vol. III, págs. 37-61.

4 Sobre los orígenes medievales de las cofradías, destacan los trabajos de Antonio MarTín-Viveros Tajuelo, «Las cofradías castellanas en la Edad Media. Pasado presente y futuro de la producción historiográfica», Espacio, Tiempo y Forma, Serie III, Historia Medieval, 25 (2012), págs. 285-308; Juan C. ArBolEDA Goldaracena, «La devoción a la Sangre de Cristo y el origen de las cofradías penitenciales a fines de la Edad Media: el caso de la ciudad de Málaga», Revista Historia Autónoma, 1 (2012), págs. 73-88.

5 Muy interesantes para calibrar la herencia medieval son los estudios de Juan C. Garrido Aguilera, Religiosidad popular en Jaén durante los siglos XV y XVI. Las cofradías, Jaén, Ayuntamiento de Jaén, 1987; José SÁnchez HerRero. "Las cofradías sevillanas. Los comienzos», Las cofradías de Sevilla: historia, antropología y arte, Sevilla, Universidad de Sevilla, 1985, págs. 9-34, o Juan C. Goldaracena Arboleda, «Creencias y devociones en las cofradías sevillanas de finales de la Edad Media y comienzos de la modernidad», Revista de Humanidades, 29 (2016), págs. 9-36.

6 Inmaculada Arias de Sanedra Alías y Miguel L. López-Guadalupe Muñoz, «Cofradías y ciudad en la España del Antiguo Régimen», Studia Historica. Historia Moderna, 19 (1998), págs. 197-228. A título de ejemplo, análisis de conjunto sobre una parroquia: Miguel L. López-Guadalupe Muñoz, Las cofradías 
abundantes, destacando los existentes sobre ciudades castellanas con gran implantación cofradiera como Toledo ${ }^{7}$, Valladolid ${ }^{8}$, Madrid ${ }^{9}$ o Palencia ${ }^{10}$, y andaluzas como Sevilla ${ }^{11}$, Granada ${ }^{12}$ y Córdoba ${ }^{13}$, así como en otras ciudades del norte

de la parroquia de Santa M. ${ }^{a}$ Magdalena de Granada en los siglos XVII y XVIII, Granada, Universidad de Granada, 1992; sobre conventos: Lázaro Gila Medina, Juan J. y Miguel L. López-Guadalupe Muñoz, Los conventos de la Merced y San Francisco, Casa Grande, de Granada. Aproximación histórico-artística, Granada, Universidad de Granada, 2002; sobre ermitas: Rafael VÁzQuez Lesmes, La devoción popular cordobesa en sus ermitas y santuarios, Córdoba, 1987; Miguel L. LóPEZ-GuAdaluPE Muñoz, «Ermitas y oratorios en las vicarías de la Costa granadina a comienzos del siglo XIX», Anuario de Estudios de la Costa granadina, 3 (1991), págs. 147-181; Santiago PÉrEz LóPEz, «Religiosidad popular en el obispado de Guadix: cofradías de culto, rogativas, ermitas y oratorios», en Antonio L. Cortés Peña y Miguel L. López-Guadalupe Muñoz (eds.), Estudios sobre Iglesia y Sociedad en Andalucía en la Edad Moderna, Granada, Universidad de Granada, 1999, págs. 355-376.

7 Mario Arellano García, «Datos para la historia de las parroquias de Toledo y las cofradías de las mismas», Toletum, 9 (1979), págs. 91-108; Hilario Rodríguez de Gracia, Cofradías toledanas, Madrid, Universidad Complutense, 1982; y Fernando MarTínez GiL, Muerte y sociedad en la España de los Austrias, Madrid, 1993, págs. 403 y sigs.

8 Entre otros trabajos destacan: Teófanes EGIDo LópEz, «La religiosidad colectiva de los vallisoletanos», en Valladolid en el siglo XVIII, Valladolid, Ateneo, 1984, págs. 157-260 y Margarita Torremocha HeRNÁNDEZ, «Cofradías y devociones. Sociabilidad y religiosidad en Valladolid», en José Alonso Ponga y M. a Pilar Panero García (coords.), Gregorio Fernández: antropología, historia y arte en el Barroco, Valladolid, Ayuntamiento de Valladolid, 2008, págs. 327-371; Javier BurRIEZA SÁnchez, Cinco siglos de cofradías y procesiones: Historia de la Semana Santa en Valladolid, Valladolid, Ayuntamiento de Valladolid, 2004.

9 Francisco Aguilar Piñal, «Asociaciones piadosas madrileñas en el siglo XVIII (Descripción bibliográfica de sus constituciones)», Anales del Instituto de Estudios Madrileños, VII (1971), págs. 253-268; Jesús Pereira Pereira, «La religiosidad y la sociabilidad popular como aspectos del conflicto social en el Madrid de la segunda mitad del siglo XVIII», en Equipo Madrid de Estudios Históricos, Carlos III, Madrid y la Ilustración, Madrid, Siglo XXI, 1988, págs. 223-254; Milagrosa Romero SAMPER, Las cofradías de Madrid en el siglo XVIII, Tesis doctoral inédita, Madrid, Universidad Complutense, 1998.

10 Véase al respecto la reciente tesis doctoral inédita de Carlos Lozano Ruiz, Las cofradías de la ciudad de Palencia en los siglos XVII y XVIII, Universidad de Valladolid, 2017.

11 Sobre cofradías sevillanas existe una bibliografía ingente; solo mencionaremos algunas obras de conjunto: Santiago Montoto de Sedas y Enrique Esquivias Franco, Cofradías sevillanas, Sevilla, 1976; Juan Carrero Rodríguez, Anales de las cofradías sevillanas, Sevilla, Castillejo, 1984; Las cofradías de Sevilla. Historia, antropología, arte, Sevilla, Universidad de Sevilla, 1985; Las cofradías de Sevilla en la Modernidad, Sevilla, Universidad de Sevilla, 1988; Las cofradías de Sevilla en el siglo de la crisis, Sevilla, Universidad de Sevilla, 1991.

12 La obra de conjunto más completa sobre las cofradías granadinas sigue siendo la tesis doctoral de Miguel L. López-Guadalupe Muñoz, Contrarreforma y cofradías en Granada. Aproximación a la historia de las cofradías y hermandades de la ciudad de Granada durante los siglos XVII y XVIII, Granada, Universidad de Granada, 1992 (ed. microficha). Para la diócesis de Guadix, Andrés GeA ARIAs, «Hermandades, Cofradías, Asociaciones. (Siglos XvI-Xx). Diócesis de Guadix-Baza», Boletín del Instituto de Estudios Pedro Suárez, 4 (1991), págs. 103-116.

13 Véanse, entre otros, los trabajos de Miguel Castillejo Gorráiz, La religiosidad popular cordobesa, Sevilla, Argantonio, 1984 y Juan Aranda Doncel, «Religiosidad popular en una ciudad andaluza del Antiguo Régimen. El movimiento cofradiero durante la segunda mitad del siglo XVIII en Córdoba», Boletín de la Real Academia de Córdoba, 113 (1987), págs. 55-78; del mismo autor, Cofradías y asistencia social en los barrios de San Juan y Todos los Santos (Trinidad), Córdoba, Hermandad del Vía Crucis, 1990; y «Cofradías penitenciales y Semana Santa en la Córdoba del siglo XVII: el auge de la etapa barroca», en VV. AA., Actas del III Congreso Nacional de Cofradías de Semana Santa, Córdoba, Cajasur, 1997, vol. I, págs. 65-118. 
del país como Santiago de Compostela ${ }^{14}$, o mediterráneas como Barcelona ${ }^{15}$, Valencia $^{16}$ y Murcia $^{17}$.

Sobre los aspectos jurisdiccionales y organizativos así como el funcionamiento interno de las cofradías no hay ningún estudio de conjunto de carácter monográfico, aunque esta cuestión se ha abordado en algunas obras de carácter general sobre las mismas ${ }^{18}$. En cambio, los estudios sobre reglas y constituciones de cofradías concretas se multiplican hasta la saciedad. Un intento recopilatorio de reglas de cofradías andaluzas de principios de la Edad Moderna se realizó en una notable edición crítica hace unos años ${ }^{19}$, que espera ser continuada en breve.

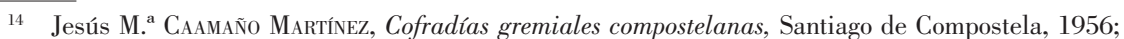
Roberto J. López López, «Las cofradías gallegas en el Antiguo Régimen», Obradoiro de Historia Moderna. Homenaje al profesor Antonio Eiras Roel en el XXV aniversario de su cátedra, Santiago de Compostela, 1990, págs. 181-200, y Domingo L. GonZÁLEz Lopo, «La evolución del asociacionismo religioso gallego en la segunda mitad del siglo XVIII en el arzobispado de Santiago», en Gremios, hermandades y cofradías, San Fernando, Ayuntamiento de San Fernando, 1992, vol. II, págs. 27-42. También en su obra de conjunto: Los comportamientos religiosos en la Galicia del Barroco, Santiago de Compostela, Xunta de Galicia, 2002.

15 Carmen Guimerá Ravina, «Les associacions religioses de laics a la Barcelona de la segona meitat del segle XVIII", en VV. AA., Actes del Primer Congrés d'Història Moderna de Catalunya, Barcelona, Universitat de Barcelona, 1984, vol. II, págs. 501-506; Joan BADA, «La vida religiosa popular a Catalunya a l'época de Carles III», Pedralbes, 8 (1988), vol. II, págs. 459-477; Martí Gelabertó Vilagrán, «Cultura popular y ceremonias religiosas en la Catalunya del siglo XVIII», Pedralbes, 8 (1988), vol. II, págs. 615-623; Anna RiERA I Mora, «Les festes religioses en el regnat de Carles III: el cas particular de Barcelona (1770-1785)», Pedralbes, 8 (1988), vol. II, págs. 605-613.

16 Son destacables los trabajos de M. Milagros Cárcel Ortí y José Trenchs Odena, «Cofradías y hermandades de Valencia (1721-1882). Documentos de tipo judicial», Estudis d'Història Contemporania del País Valenciá, 3 (1982), págs. 285-319 y Manuel Benítez Bolorinos, «Las cofradías en el Reino de Valencia: análisis y claves interpretativas», Anuario de Estudios Medievales, 35-2 (2006), págs. 553-581.

17 Farid ABBAD, «Una aportación al estudio de las cofradías murcianas en el siglo XVIII», Murcia, 11(1977), s. p.; Antonio Peñafiel Ramón Mentalidad y religiosidad popular murciana en la primera mitad del siglo XVIII, Murcia, Universidad de Murcia, 1988.

18 Es el caso de Inmaculada Arias de Sanvedra Alías y Miguel L. López-Guadalupe Muñoz, «Las cofradías y su dimensión social en la España del Antiguo Régimen», Cuadernos de Historia Moderna, 25 (2000), págs. 189-232. Algunos estudios de casos: Domingo A. López Fernández, «Organización y fines de las Hermandades y Cofradías en el pasado. El caso particular de la costa granadina», en VV. AA., Actas de las Jornadas de Cofradías. Diócesis de Granada y Guadix-Baza, Granada, Federación de Cofradías de Granada, 1995, págs. 35-45; Miguel L. LóPEz-Guadalupe Muñoz, «Religiosidad popular y jerarquías. Cofradías y sociedad en la España moderna», en José Ruiz Fernández y Valeriano Sánchez Ramos (coords.), La Religiosidad Popular y Almería, Almería, Instituto de Estudios Almerienses, 2001, págs. 181-196; Marion REDER GADOW «La organización de las Cofradías andaluzas. El ejemplo de Málaga», Andalucía en la Historia, 15 (2007), págs. 10-16. Destaca por su especificidad Miguel J. Lara Ródenas, «Organización interna y estructuras de poder en las hermandades de Huelva durante el Antiguo Régimen», en Gremios, hermandades, vol. I, págs. 215-241.

19 José SÁnchez Herrero y Silvia M. a Pérez GonzÁlez (coords.), CXIX reglas de hermandades y cofradías andaluzas: siglos XIV, XV y XVI, Huelva, Universidad de Huelva, 2013. 


\section{Tipologías confraternales}

La realidad cofrade a lo largo del Antiguo Régimen era de una gran complejidad. Al lado de cofradías y hermandades propiamente dichas, con un número de hermanos generalmente amplio, cuadros directivos bien estructurados y actividades regladas a lo largo de todo el año, existían las llamadas mayordomías, en las que la estructura organizativa de la cofradía era prácticamente inexistente. Se limitaban estas mayordomías a la celebración de las fiestas patronales, en las que participaban todos los vecinos, fiestas que solían ser costeadas por los mayordomos, elegidos por turno para tal fin. La mayordomía era la realidad cofrade más simple ${ }^{20}$.

En cuanto a las cofradías propiamente dichas, aunque todas tenían como principal objetivo contribuir al culto divino y a la asistencia a sus miembros, según su distinta orientación, encontramos cofradías de diversas tipologías: cofradías devocionales (las más frecuentes, que tenían como único objetivo el culto a la Virgen, los santos, el Santísimo Sacramento o las ánimas del purgatorio), cofradías penitenciales (que se centraban en la conmemoración de la pasión y muerte de Jesucristo), cofradías gremiales (que junto a la faceta cultual tenían un componente profesional y reivindicativo muy claro) y cofradías asistenciales (donde la labor benéfica, existente en todas las cofradías en mayor o menor grado, adquiría una especial dimensión y salía del propio ámbito de sus hermanos; asistencia a pobres, hospitales o enseñanza eran sus principales objetivos). Por último, hay que tener en cuenta un tipo de hermandades mucho más minoritarias, las congregaciones, que respondían a las necesidades espirituales de individuos más inquietos y alentaban la fe individual con prácticas diarias. A continuación, vamos a hacer una breve aproximación a los desarrollos historiográficos habidos en los últimos años sobre ellas.

Las cofradías más frecuentes son las que podemos llamar devocionales, que tenían por objeto el culto a la Virgen, a los santos, al Santísimo Sacramento o a las ánimas benditas del purgatorio. Comparten esa dimensión devocional, pero con una especial significación, las cofradías penitenciales, que conmemoran la pasión y muerte de Jesucristo. Con su origen en la baja Edad Media, quedaron plenamente constituidas durante el siglo XVI, experimentando un notable desarrollo en los siglos siguientes. Son las que han recibido mayor atención, sin duda alguna por ser las de mayor pervivencia en el tiempo y tener una gran presencia en la actualidad. Sus componentes se han preocupado por conocer su historia y

20 La bibliografía sobre mayordomías es prácticamente inexistente. Un estudio reciente sobre una de ellas a lo largo del tiempo en Miguel Á. García NaVArRete, La mayordomía y la cofradía de Nuestra Señora del Collado de Santisteban del Puerto, Trabajo Fin de Máster inédito, Universidad de Granada, 2016. 
orígenes. Además, la celebración de seis congresos nacionales de cofradías $^{21}$ ha contribuido a propiciar un abundante desarrollo historiográfico ${ }^{22}$. No han faltado tampoco congresos monográficos sobre algún tipo concreto de estas cofradías penitenciales, como las de la Vera $\mathrm{Cruz}^{23}$, de Jesús Nazareno ${ }^{24}$ o del Santo Entierro $^{25}$, también sobre su incidencia en ciudades o zonas más concretas ${ }^{26}$, e incluso algún estado de la cuestión, si bien parcial, sobre el tema ${ }^{27}$. El resultado de todo ello es una bibliografía abundantísima donde, junto a innumerables trabajos de corte positivista y descriptivo, la mayoría de las veces centrados en cofradías concretas, no han faltado visiones de conjunto e intentos de sistematización ${ }^{28}$, produciéndose además investigaciones monográficas sobre áreas concretas ${ }^{29}$.

21 VV. AA., Actas I Congreso Nacional de Cofradías de Semana Santa, Zamora, Diputación Provincial de Zamora, 1987; Juan Aranda Doncel (dir.), Actas del III Congreso Nacional de Cofradías de Semana Santa, Córdoba, Cajasur, 1997; Juan Aranda Doncel (coord.), Cofradías Penitenciales y Semana Santa. Actas del V Congreso Nacional de Cofradías de Semana Santa, Zaragoza, 2006; Juan Aranda Doncel (coord.), Actas del Congreso Nacional de Cofradías de Semana Santa, Córdoba, Diputación Provincial de Córdoba, 2012.

22 Una aproximación en José Sánchez Herrero y Juan A. Ruiz Domínguez, «Las cofradías de Semana Santa: balance de situación y vías de renovación [Bibliografía]», en Juan Aranda Doncel (dir.), Actas del III Congreso Nacional de Cofradías de Semana Santa, vol. I, págs. 23-64.

${ }^{23}$ José SÁnchez Herrero (ed.), Las cofradías de la Santa Vera Cruz. Actas del I Congreso Internacional de Cofradías de la Santa Vera Cruz, Sevilla, Centro de Estudios e Investigación de la Religiosidad Andaluza, 1995; José A. Casquero Fernández (coord.), Actas del IV Congreso Internacional de Hermandades y Cofradías de Vera Cruz, Zamora, Cofradía de la Santa Vera Cruz de Zamora, 2009. Más recientemente la síntesis de José Sánchez Herrero, «La devoción a la Vera Cruz (Lignum Crucis) y las Cofradías de la Vera Cruz», Tercerol. Cuadernos de investigación, 16 (2013), 99-146.

24 Juan Aranda Doncel (coord.), Actas del Congreso Internacional Cristóbal de Santa Catalina y las Cofradías de Jesús Nazareno, Córdoba, 1991. Otros encuentros de esta modalidad penitencial son: Juan Aranda Doncel (coord.), La advocación de Jesús Nazareno. Actas del Congreso Nacional, Pozoblanco, Ayuntamiento de Pozoblanco, 2007; Jesús Negroles SÁnchez (coord.), Actas del III Congreso Nacional Advocación de Jesús Nazareno, Cartagena, Agrupación de Nuestro Padre Jesús Nazareno de la Real e Ilustre Cofradía de Nuestro Padre Jesús Nazareno, 2009, o Fermín Labarga GarCía (coord.), Camino del Calvario: rito, ceremonia y devoción. Cofradías de Jesús Nazareno y figuras bíblicas, V Congreso Nacional de Cofradías bajo la Advocación de Jesús Nazareno, Córdoba, Diputación Provincial de Córdoba, 2015.

25 VV. AA., Actas del III Encuentro para el estudio cofradiero: En torno al Santo Sepulcro, Zamora, Instituto de Estudios Zamoranos Florián de Ocampo, 1995.

${ }_{26}$ Numerosas son, por ejemplo, las reuniones científicas centradas en las hermandades de Sevilla y su provincia, en los que han tenido una fuerte presencia las hermandades penitenciales; la más reciente es XVII Simposio sobre Hermandades de Sevilla y su provincia, Sevilla, Fundación Cruzcampo, 2016.

27 Federico Fernández Basurte, «Aproximación historiográfica a la dinámica de las Cofradías de Pasión: estado de la cuestión en torno al caso de Málaga», Baetica. Estudios de Arte, Geografía e Historia, 18 (1996), págs. 359-378.

28 José Sánchez Herrero, «Las cofradías de Semana Santa en la Modernidad. Siglos XV al xvIII», en VV. AA., Actas I Congreso Nacional de Cofradías de Semana Santa, Zamora, Diputación Provincial de Zamora, 1987, págs. 27-68; José M. a Miura Andrades, Isabel Montes Romero-Camacho y José Sánchez Herrero, «Los cuatro tipos diferentes de cofradías de Semana Santa: desde su fundación hasta la crisis de finales del siglo XVIII en la Andalucía Bética y Castilla», en VV. AA., I Congreso Nacional de Cofradías de Semana Santa, págs. 259-303.

29 Rafael Á. Martínez González, Las cofradías penitenciales de Palencia, Palencia, Caja de Ahorros de Palencia, 1979; Miguel L. López-Guadalupe Muñoz, «Las cofradías de penitencia de Granada en la Edad 
A pesar de la relevancia y pervivencia de las cofradías penitenciales, no eran éstas las más difundidas durante los siglos modernos, sino que eran las marianas las más populares y numerosas, pues la devoción a la Virgen ha estado siempre muy arraigada en las gentes sencillas de nuestro país. La figura de la madre protectora que auxilia en los problemas y dificultades era esencial en unas vidas difíciles, como eran las de las clases populares del Antiguo Régimen. Aunque no se puede establecer un cálculo exacto, no es exagerado pensar que un tercio de las cofradías existentes a finales del Antiguo Régimen eran cofradías marianas ${ }^{30}$. En ciudades como Murcia o Madrid sobrepasaban el 40 por ciento del total de cofradías, y en Córdoba y Valladolid estaban muy próximas a estos valores ${ }^{31}$. Las advocaciones marianas eran muy variadas, pero había algunas especialmente extendidas, dentro de un amplio abanico de posibilidades ${ }^{32}$.

Especialmente populares eran las que tenían por advocación la Virgen del Rosario, fomentadas por los dominicos. A finales del Antiguo Régimen prácticamente en todos los pueblos existía alguna hermandad rosariana, e incluso en algunas ciudades podía haber varias con sede en las distintas parroquias ${ }^{33}$. En la diócesis de Granada se acercaban al centenar y han sido objeto de estudio ${ }^{34}$. También han sido objeto de atención historiográfica las de Córdoba, Granada y sobre todo las de Sevilla ${ }^{35}$, así como la extensión de esta devoción por Andalu-

Moderna», Gazeta de Antropología, 11 (1995), págs. 103-108; Ernesto García Fernández, «Las hermandades y cofradías de la Vera Cruz en el País Vasco», Hispania Sacra, LXI-124 (2009), págs. 447-482.

30 Arias de Saavedra Alías López-Guadalupe Muñoz, «Cofradías y ciudad», pág. 203; Juan C. Arboleda Goldaracena, «Contrarreforma y religiosidad popular en Andalucía: cofradías y devoción mariana», Tiempos Modernos. Revista electrónica de Historia Moderna, vol. 7, 20 (2010), págs. 1-23.

31 Arias de SaAvedra Alías y López-Guadalupe Muñoz, «Cofradías y ciudad», págs. 202-203.

32 Joël SAUGNiEuX, «llustración católica y religiosidad popular: el culto mariano en la España del siglo XVIII ", en VV. AA., La época de Fernando VI, Oviedo, Centro de Estudios del Siglo XVIII, 1981, págs. 275295. Entre las obras colectivas: Juan Aranda Doncel (coord.), I Congreso Nacional Las advocaciones marianas de gloria, Córdoba, CajaSur, 2003.

33 En Valladolid, por ejemplo, en 1771 había diez cofradías del Rosario, ubicadas en las parroquias de S. Miguel, Santiago, S. Salvador, Ntra. Sra. de la Antigua, S. Julián, S. Martín, la Magdalena, S. Juan, S. Pedro y S. Ildefonso (Arias de Saavedra Alías y López-Guadalupe Muñoz, "Cofradías y ciudad», pág. 203).

34 Miguel L. López-Guadalupe Muñoz, «Implantación de las cofradías en la diócesis de Granada durante la Edad Moderna», en Juan Aranda Doncel (coord.), Congreso de Religiosidad popular en Andalucía, Cabra, Cajasur, 1994, págs. 101-140, y Miguel L. LóPEZ-Guadalupe Muñoz «Expansión y control de las cofradías en la España del siglo xvı. Aspectos de la vida cotidiana», en Juan L. Castellano Castellano y Francisco Sánchez-Montes González (coords.), Carlos V. Europeísmo y universalidad, Madrid, Sociedad Estatal para la Conmemoración de los Centenarios de Felipe II y Carlos V, 2001, vol. V (Religión, cultura y mentalidad), págs. 377-416.

35 Manuel Moreno Valero, «La religiosidad popular en Córdoba en el siglo XviII. Cofradías del Santo Rosario», en León C. Álvarez Santaló, M. 'Jesús Buxó y Salvador Rodríguez Becerra (coords.), La religiosidad popular, Barcelona, Anthropos, 1989, vol. III, págs. 485-506; Juan ARANDA Doncel, «Cofradías rosarianas en la Córdoba del siglo xviII. Las hermandades de Ntra. Sra. de los Afligidos y del Auxilio», Boletín de la Real Academia de Córdoba, 155 (2008), págs. 123-135. Para Granada: Miguel L. López-Guadalupe Muñoz, «Ex- 
cía e incluso por toda España ${ }^{36}$. Otras advocaciones marianas muy extendidas eran la Ntra. Sra. del Carmen, de los Dolores, de la Esperanza, etc. Así mismo, en el siglo XVIII se difundió la devoción de la Divina Pastora, propiciada por los capuchinos $^{37}$.

La devoción a los santos, sancionada por el Concilio de Trento y extendida por toda la Iglesia Católica, también se materializaba en la existencia de cofradías, que contaban en nuestro país con un fuerte arraigo popular. Las cofradías con advocaciones de santos presentaban valores cercanos a las cofradías marianas. En Navarra y Murcia, por ejemplo, superaban el 34 y el 30 por ciento respectivamente, del total de hermandades a fines del Antiguo Régimen $^{38}$. Casi todos los pueblos, además de la patrona, solían tener un santo patrón. La variedad de titularidades de estas cofradías era enorme y muchas estaban ligadas a las actividades socio-profesionales de la época: desde las de santos relacionados con la agricultura (S. Isidro, S. Antón, S. Pascual Bailón) que agrupaban a agricultores y ganaderos, a las relacionadas con una gran variedad de oficios: las dedicadas a San José para carpinteros ${ }^{39}$ y albañiles, las de San Eloy para los plateros, San Cosme y San Damián para los médicos, Santos Crispín y Crispiniano para los zapateros, etc. A advocaciones de santos estaban dedicadas casi todas las cofradías gremiales, de una fuerte presencia urbana,

pansión de las cofradías del Rosario en la diócesis de Granada en la época moderna», en Congreso Internacional del Rosario, Sevilla, Ayuntamiento de Sevilla / CajaSur, 2004, págs. 379-389; José A. Palma Fernández, «La devoción al Santo Rosario en Granada y su provincia. Historia, arte y tradición», en José A. Peinado Guzmán y M. ${ }^{a}$ del Amor Rodríguez Miranda (coords.), Meditaciones en torno a la devoción popular, Córdoba, Asociación para la investigación de la Historia del Arte y el Patrimonio Cultural Hurtado Izquierdo, 2016, págs. 377-396. Para Sevilla, destacan sobre todo los trabajos de Carlos J. Romero Mensaque, El Rosario en Sevilla. Religiosidad popular y hermandades de Gloria, Sevilla, Eco 21, 1990; Carlos J. Romero MensaQue, Estudio histórico de las hermandades de gloria de Nuestra Señora del Rosario de la ciudad de Sevilla y descripción artística de su patrimonio, Sevilla, Caja San Fernando,1990; Carlos J. Romero Mensaque, «La conformación popular del universo religioso: los rosarios públicos y sus hermandades en Sevilla durante el siglo XVIII", en Salvador Rodríguez Becerra (coord.), Congreso de religiosidad popular, Andújar, Junta de Andalucía, 1999 , vol. I, págs. 427-438; Carlos J. Romero Mensaque, «El Rosario público en la Sevilla del siglo XviII. Datos para un repertorio de cofradías, hermandades y congregaciones del Santo Rosario», en VV. AA., Las advocaciones marianas de Gloria, Córdoba, Cajasur, 2003, vol. I, págs. 259-283, y Carlos J. Romero MensaQue, El rosario en Sevilla. Devoción, rosarios públicos y hermandades, Sevilla, RD Editores 2004.

36 Carlos J. Romero Mensaque, «El Rosario y sus cofradías en Andalucía. Una aproximación histórica», Hispania Sacra, LXII-126 (2010), págs. 621-659, y del mismo autor: «La universalización de la devoción del Rosario y sus cofradías en España», Angelicum, vol. 90, 1(2013), págs. 217-246. Y en general: VV. AA., Congreso Internacional del Rosario, Sevilla, Ayuntamiento de Sevilla / CajaSur, 2004.

37 Ramón de la Campa Carmona, «La génesis de la advocación mariana de la Divina Pastora en su contexto socio-histórico», en Jesús Paniagua Pérez (coord.), España y América entre el Barroco y la Ilustración (1722-1804), León, Universidad de León, 2005, págs. 607-624.

38 Arias de Saavedra Alías y López-Guadalupe Muñoz, «Cofradías y ciudad», pág. 206.

39 Miguel L. López-Guadalupe Muñoz, «La Hermandad de Carpinteros de San José de Granada. Diseño y realidad de una cofradía gremial», Estudios Josefinos, 48 (1994), págs. 3-25. 
que constituyen una tipología especial, a la que nos referiremos más adelante. En el siglo XVIII los santos más populares, por la frecuencia de advocaciones encontradas, eran San José, San Antonio, San Sebastián y San Roque, estos dos últimos protectores frente a la peste. Los estudios realizados en fechas recientes sobre las cofradías con advocaciones de santos están marcados por la atomización, un cierto localismo y en muchos casos ceñidos al análisis de una cofradía concreta. En un trabajo de las características del que nos ocupa, no es posible, por tanto, hacer una referencia pormenorizada a los mismos, solo destacaremos el interés prestado al desarrollo de la devoción a San José, impulsada por la jerarquía eclesiástica y que arraigó con éxito a fines del Antiguo Régimen, dentro de un modelo de religiosidad más humanizada y familiar que se vivía en la época ${ }^{40}$.

La devoción a la figura de Cristo no cristalizó tan frecuentemente en la creación de cofradías, a juzgar por el número de las dedicadas a sus advocaciones. Y eso a pesar de que entre ellas se encontraban muchas de las cofradías penitenciales anteriormente aludidas, que tenían advocaciones cristológicas, como ocurría con las de la Vera Cruz o el Nazareno, dos de las titularidades más frecuentes y arraigadas entre las dedicadas a los cultos de Semana Santa, en una época en que entre las hermandades penitenciales las advocaciones marianas tenían una menor relevancia de la que tienen en la actualidad. Otras advocaciones, como el Dulce Nombre de Jesús ${ }^{41}$, o el Corazón de Jesús, tuvieron una significación mucho menor, a pesar de los esfuerzos de los dominicos y de los jesuitas, respectivamente, por difundirlas. Se trataba de devociones más minoritarias y que respondían a un sentido religioso más profundo: las primeras se proponían desterrar la blasfemia, las segundas destacaron en la práctica de la caridad; ambas establecieron pautas diarias de espiritualidad para sus miembros.

También a un sentido religioso más profundo y a unas mayores exigencias espirituales respondían las cofradías sacramentales y de ánimas, dedicadas a promover el culto eucarístico y los sufragios por las almas de los difuntos. Eran cofradías típicamente parroquiales, que prestaban un importante apoyo al culto. El culto al Santísimo Sacramento y a las ánimas benditas del Purgatorio solía darse en hermandades separadas, pero en algunas ocasiones se hacía en el seno de la misma cofradía, casi siempre como resultado de un proceso de

40 Teófanes Egido López y José L. Rodríguez, «La devoción popular a San José en el Antiguo Régimen», Estudios Josefinos, XXXVIII-76 (1984), págs. 159-184. Un estudio sobre sus cofradías en Francisco J. Campos y Fernández de Sevilla, Cofradías de San José en el mundo hispánico, San Lorenzo del Escorial, Instituto Escurialense, 2014.

41 Valeriano SÁnchez Ramos, «El Dulce Nombre de Jesús: una devoción popular al santo Niño en los ciclos de Navidad y Semana Santa», Revista Vera Cruz, 18 (2001), págs. 5-12. 
fusión entre dos hermandades previas. Algunas de estas cofradías mixtas han sido objeto de estudios muy detallados y solventes ${ }^{42}$. También han sido objeto de estudios monográficos las hermandades sacramentales de Sevilla, Granada, Jaén y Córdoba ${ }^{43}$. En este caso ha sido trascendental para el estudio de esta tipología de cofradías la celebración de congresos y la edición de volúmenes monográficos sobre las mismas ${ }^{44}$. En cuanto a las cofradías de ánimas, dejando de lado visiones más concretas, cabe destacar un trabajo reciente sobre las cofradías de ánimas gaditanas y otro donde se realiza una aproximación a estas cofradías a través de sus constituciones, no solo en el ámbito peninsular, sino también en América ${ }^{45}$.

Especialmente significativas en el mundo urbano eran las cofradías gremiales, que junto a la dimensión religiosa tenían un componente profesional y reivindicativo muy fuerte ${ }^{46}$. A veces cofradía y gremio se confunden, otras veces mantienen su autonomía, y entre uno y otro extremo se constatan diversas situaciones intermedias. Las atribuciones específicas de las cofradías gremiales parecen claras, al lado del culto al santo patrón de una actividad profesional concreta, se llevan a cabo medidas benéficas a favor de los agremiados ${ }^{47}$. Al acercarnos a la producción historiográfica sobre las mismas, no debe olvidarse que los primeros estudios sobre cofradías aparecidos en la primera mitad del

42 Margarita Torremocha Hernández, Solidaridad en el más allá. La Cofradía Sacramental y de Ánimas de la Iglesia de la Magdalena de Valladolid, Valladolid, Ayuntamiento de Valladolid / Instituto Simancas, 2003.

43 José Roda Peña, Hermandades sacramentales de Sevilla. Una aproximación a su estudio, Sevilla,

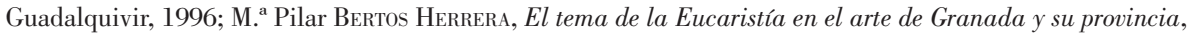
Granada, Universidad de Granada, 1986, 2 vols.; o Miguel L. López-Guadalupe Muñoz, «El Corpus Christi y las Hermandades Sacramentales en la Granada Moderna», en Minerva. Liturgia, fiesta y fraternidad en el Barroco español, Sepúlveda, Cofradía del Corpus de Sepúlveda, 2008, págs. 253-27; Rosario Anguita HerraDOR, Arte y culto. El tema de la Eucaristía en la provincia de Jaén, Jaén, Universidad de Jaén, 1996; Miguel Ventura Gracia, Las cofradías cordobesas del Santísimo Sacramento. El caso de Espejo en la Edad Moderna, Córdoba, Universidad de Córdoba, 2010.

${ }^{44}$ Minerva. Liturgia, fiesta y fraternidad en el Barroco español. Actas del I Congreso Nacional de Historia de las Cofradías Sacramentales, Sepúlveda, Cofradía del Corpus de Sepúlveda, 2008; Fermín Labarga García, Festivas demostraciones: estudios sobre las cofradías del Santísimo y la fiesta del Corpus Christi, Logroño, Instituto de Estudios Riojanos, 2010.

45 Raquel Sigüenza Martín y José M. ${ }^{a}$ Collantes González, «La devoción a las ánimas del Purgatorio en Cádiz: dos hermandades para su estudio», Trocadero, 26 (2014), págs. 1-25; Francisco J. Campos y FERnáNDEZ DE SEviLla, «Religiosidad popular en las reglas de las constituciones de cofradías de ánimas en el mundo hispánico», en Francisco J. Campos y Fernández de Sevilla (coord.), El mundo de los difuntos: culto, cofradías y tradiciones, San Lorenzo del Escorial, Ediciones Escurialenses, 2014, págs. 1089-1132.

46 Sirva de ejemplo Antonio Domínguez Ortiz, «Aspectos sociales de las cofradías sevillanas. Un Memorial de la Cofradía de las Tres Caídas, de San Isidoro, en defensa de los cocheros», Archivo Hispalense, vol. XXX, 93-94 (1959), págs. 167-170.

47 Pudieron derivar en montepíos: José M. Ponce Ramos, La Hermandad y Montepío de Viñeros en la Edad Moderna, Málaga, Diputación Provincial de Málaga, 1995. 
siglo xx las abordaron desde su imbricación con el mundo corporativo, como ocurre con los estudios ya clásicos del marqués de Lozoya ${ }^{48}$, o con la obra de Rumeu de Armas sobre la previsión social en España ${ }^{49}$. Las investigaciones realizadas a partir de la década de los setenta del pasado siglo sobre el mundo gremial incluían interesantes referencias a estas $\operatorname{cofradías}^{50}$. No hay que olvidar tampoco la celebración de algún congreso que puso el acento en este tipo de cofradías ${ }^{51}$. Con relación a estas últimas, la historiografía más reciente ha prestado atención a su abundante actividad festiva, origen en muchos casos de conflictividad social, así como a la conflictividad intragremial suscitada por la endogamia y el control de los cargos ${ }^{52}$.

\section{Un «redescubrimiento» esencial: la dimensión asistencial}

En las cofradías asistenciales la labor benéfica, existente en todas las cofradías en mayor o menor grado, adquiría una dimensión muy destacada, desbordando el conjunto cerrado de los cofrades y abriéndose a los sectores más desfavorecidos de la sociedad. La labor benéfico-social de las cofradías ha sido una de las realidades más atendidas en los últimos años ${ }^{53} \mathrm{y}$ ha dado lugar incluso a un reciente estado de la cuestión historiográfico, centrado específicamente en

48 Juan de Contreras (Marqués de Lozoya), Historia de las corporaciones de menestrales en Segovia, Segovia, Mauro Lozano, 1921.

49 Antonio Rumeu de Armas, Historia de la previsión social en España. Cofradías, gremios, hermandades, montepíos, Madrid, Revista Derecho Privado, 1944 (una edición facsimilar más reciente: Barcelona, El Albir, 1981).

50 Sin ánimo de exhaustividad pueden citarse las más relevantes (algunas constituyeron tesis doctorales en su día): Pedro Molas Ribatta, Los gremios barceloneses del siglo XVIII. La estructura corporativa ante el comienzo de la revolución industrial, Madrid, Confederación Española de Cajas de Ahorros, 1970; Baudilio Barreiro Mallón, «Los gremios compostelanos. Algunos datos y reflexiones», Liceo Franciscano, 29 (1976), págs. 119-149; Siro Villas Tinoco, Los gremios malagueños (1700-1746), Málaga, Universidad de Málaga, 1982, 2 vols.; Máximo García Fernández, Los gremios, Valladolid, Caja de Ahorros Popular, 1987, y del mismo autor: Los viejos oficios vallisoletanos, Valladolid, Michelín, 1996; Antonio M. Moral Roncal, Gremios e Ilustración en Madrid (1775-1836), Madrid, Actas, 1998; Juan C. Zofío Llorente, Las culturas del trabajo en Madrid, 1500-1650: Familia, ocio y sociabilidad en el artesanado preindustrial. Tesis Doctoral, Universidad Complutense, 2002.

51 VV. AA., Gremios, hermandades y cofradías: una aproximación científica al asociacionismo profesional y religioso en la historia de Andalucía: Actas de los VII encuentros de Historia y Arqueología, San Fernando, Fundación Municipal de Cultura, 1991.

52 Máximo GarCía Fernández, «Gremios y pleitos. Comportamientos sociales y laborales restrictivos en la Castilla interior de los siglos XVI-XVIII", Erasmo. Revista de Historia Bajomedieval y Moderna, 3 (2016), págs. 39-54.

53 Clásico resulta ya el trabajo de William J. Callahan, «Caridad, sociedad y economía en el siglo XVIII», Moneda y crédito, 146 (1978), págs. 65-77. 
estas cofradías $^{54}$. Aunque en algún trabajo se plantea la labor benéfica de las cofradías de manera global, atendiendo a los auxilios diversos prestados por estas instituciones referentes al conjunto de las obras de misericordia ${ }^{55}$, analizando de forma global la acción benéfico social de las cofradías en ámbitos geográficos concretos, como el andaluz ${ }^{56}$, la mayoría de los trabajos se han centrado en la labor desarrollada por las cofradías frente a la enfermedad, prestando especial atención a la asistencia hospitalaria mantenida por ellas. Se trataba en la mayoría de los casos de una asistencia dirigida a los propios cofrades, pero en otros se abría al conjunto de la sociedad, especialmente a los colectivos más desfavorecidos, como ocurría en las cofradías hospitalarias. Este tipo de hermandades fueron poco numerosas, debido a que la gran exigencia de recursos que precisa cualquier centro hospitalario no estaba al alcance de la mayoría. Las más destacadas, como las hermandades del Refugio de Madrid, de la Caridad y Refugio de Granada, o de la Caridad de Sevilla han sido objeto de diversos estudios ${ }^{57}$.

54 Carlos Lozano Ruiz y Margarita Torremocha Hernández, «Asistencia social y cofradías en el Antiguo Régimen. Historiografía, líneas de investigación y perspectivas», Chronica Nova, 39 (2013), págs. 19-46.

55 Maureen Flynn, Sacred Charity: Confraternities and Social Welfare in Spain (1400-1700), London, Palgrave Macmillan, 1989.

56 Es muy destacable en este sentido el trabajo de Miguel L. López-Guadalupe Muñoz, La labor benéfico-social de las cofradías en la Granada Moderna, Granada, Universidad de Granada, 1994, así como la reflexión de Juan I. García Carmona, «Cofradías y asistencia en el Quinientos: Una valoración crítica», en León C. Álvarez Santaló (coord.), Estudios de Historia Moderna en homenaje al profesor Antonio GarcíaBaquero, Sevilla, Universidad de Sevilla, 2009, págs. 273- 286. Estudios sectoriales en Pedro Pablo HerrerA MESA, «La práctica de las obras de misericordia en las cofradías cordobesas, siglos XIV-XVII», en Francisco J. Campos y Fernández de Sevilla (coord.), La Iglesia española y las instituciones de caridad, San Lorenzo del Escorial, Ediciones Escurialenses, 2006, págs. 99-122; Juan ARANDA DoncEL, «Cofradías y asistencia social en la diócesis de Córdoba durante los siglos XVI y XVIII: las Hermandades de la Santa Caridad», en Francisco J. Campos y Fernández de Sevilla (coord.), La Iglesia española y las instituciones de caridad, págs. 123150; Adela TARIFA FERnÁNDEZ, "Cofradías y hermandades entre la religiosidad popular y la asistencia social. Aproximación a su historia en Jaén y en Úbeda», en VV. AA., Minerva. Liturgia, fiesta y fraternidad en el Barroco español, Sepúlveda, 2008, págs. 323-351. No faltan casos particulares como Pedro J. Moreno de Soto, «La Cofradía de la Santa Caridad (siglos XVI-XIX): cuatro siglos de asistencia a los pobres de Osuna», en José Roda Peña (coord.), II Simposio sobre hermandades de Sevilla y su provincia, Sevilla, Fundación Cruzcampo, 2001, págs. 131-158, o, ya fuera del ámbito andaluz, M. a del Carmen Ansón Calvo y Fernando Manzano Ledesma, «La labor benéfico-social y las ayudas mutuas en la Cofradía de las Ánimas del Purgatorio de la villa de Benavente según sus Ordenanzas de 1552», Brigecio: Revista de estudios de Benavente y sus tierras, 13 (2003), págs. 121- 132.

57 William J. Callahan, La Santa Hermandad del Refugio y Piedad de Madrid, 1618-1832, Madrid, Instituto de Estudios Madrileños, 1980; Miguel L. López-Guadalupe Muñoz y Rafael López Moya, La Hermandad de la Caridad y Refugio de Granada. 500 años de hospitalidad, Granada, Ayuntamiento de Granada, 2013. En el caso sevillano está estudiado sobre todo el Hospital de la Caridad, predominando el punto de vista artístico: Jonathan Brown, «Jeroglíficos de muerte y salvación», en Imágenes e ideas de la pintura española del siglo XVII, Madrid, Alianza Forma, 1980, págs. 149-209, y Enrique Valdivieso y Juan M. SERRERA Contreras, El Hospital de la Caridad de Sevilla, Valladolid, Sever Cuesta, 1980. Un resumen de la historia de la hermandad, en Jonathan Brown, «Hieroglyphs of Death and Salvation: The Décoration of the Church of the Hermandad de la Caridad», Art Bulletin, 52 (1970), págs. 265-277. 
La asistencia hospitalaria de las cofradías fue abordada ya en las obras clásicas sobre la asistencia social en España de Hernández Iglesias y Jiménez Salas, donde se prestaba atención a esta cuestión ${ }^{58}$, sin olvidar la ya citada obra de Rumeu de Armas, que supuso también una aportación esencial para el conocimiento de la hospitalidad cofrade. Posteriormente los estudios monográficos realizados durante las décadas de los 70 y 80 sobre la asistencia hospitalaria en diversas ciudades y regiones del país proporcionarían mayor información sobre las acciones de las cofradías profesionales y las hermandades de caridad vinculadas a ellas ${ }^{59}$. En los últimos años siguen produciéndose aportaciones en este campo $^{60}$. Otros muchos estudios de carácter más parcial han prestado atención a las cofradías hospitalarias, citarlos aquí excede las pretensiones de este trabajo. Investigaciones recientes se han centrado en otro aspecto de la asistencia cofrade en la enfermedad hasta ahora no abordado, la asistencia domiciliaria a los enfermos, que se ha planteado no solo en ejemplos concretos, sino también desde una perspectiva más amplia ${ }^{61}$.

58 Fermín Hernández Iglesias, La beneficencia en España, Madrid, Establecimientos Tipográficos de Manuel Minuesa, 1876, 2 vols.; María JimÉnez SaLAs, Historia de la asistencia social en España en la Edad Moderna, Madrid, CSIC, 1958.

59 Destacan, entre otros, los estudios de Mariano Pina Rabadán, El sector sanitario-benéfico de la antigua Zaragoza, Zaragoza, Institución Fernando el Católico, 1972; Jesús M. ${ }^{a}$ Palomares Ibáñez, La asistencia social en Valladolid. El Hospicio de Pobres y la Real Casa de Misericordia (1724-1847), Valladolid, Diputación Provincial, 1975; Alberto Marcos Martín, «El sistema hospitalario de Medina del Campo en el siglo XVI», Cuadernos de Investigación Histórica, 2 (1978), págs. 341-362; Juan I. Carmona García, El sistema de la hospitalidad pública en la Sevilla del Antiguo Régimen, Sevilla, Diputación Provincial de Sevilla, 1979; Elena MAZa Zorrilla, Valladolid, sus pobres y la respuesta institucional (1750-1900), Valladolid, Universidad de Valladolid / Junta de Castilla y León, 1985; Manuel Zamora Bermúdez, Estructura benéfico-sanitaria en la Málaga de fines del siglo XVI. Hospitales de San Julián y San Juan de Dios, Málaga, Universidad de Málaga, 1987; Pedro Carasa Soto, Crisis del Antiguo Régimen y acción social en Castilla, Madrid, Consejería de Cultura y Bienestar Social, 1988; Pedro Carasa Soto, Historia de la Beneficencia en Castilla y León, Valladolid, Universidad de Valladolid, 1991; M. a del Prado de la Fuente GaLÁn, «Aportación al estudio de los sectores marginados de la población: Pobreza, caridad y beneficencia en la España Moderna», Revista de demografía histórica, 18 (2000), págs. 13-28. Para el caso específico de atención a peregrinos, M. ${ }^{a}$ Victoria SáEnz TERREros, El Hospital de Peregrinos y la Cofradía de Santo Domingo de la Calzada. Desde su fundación hasta la crisis del Antiguo Régimen, Logroño, Instituto de Estudios Riojanos, 1996.

${ }^{60}$ Alfredo Martín García y M. José Pérez Álvarez, «Hospitalidad y asistencia en la provincia de León a finales del Antiguo Régimen», Dynamis, 27 (2007), págs. 157-185, o Inmaculada Arias de SAAVEDRA Alías y Miguel L. López-Guadalupe Muñoz, «Asistencia sanitaria femenina a finales del Antiguo Régimen: el caso del hospital de la Caridad y Refugio de Granada», Cuadernos de Historia Moderna. Anejos, XIV (2015), págs. 33-61.

61 Alberto Marcos Martín, «Asistencia domiciliaria en la España del Antiguo Régimen: el caso de la cofradía de la caridad de Palencia», en M. a José Pérez Álvarez y M. a Marta Lobo de Araujo (coords.), La respuesta social a la pobreza en la Península Ibérica durante la Edad Moderna, León, Universidad de León, 2014, págs. 89-110, y Miguel L. López-GuAdalupe MuÑoz, «Sanidad doméstica, solidaridad corporativa: las cofradías ante la enfermedad en la España Moderna», en Laurinda Abreu (coord.), Asistencia y caridad como estrategias de intervención social: Iglesia, Estado y Comunidad (siglos XV-XX), Bilbao, Universidad del País Vasco, 2007, págs. 73-94. 
Otra importante faceta donde se desplegó la labor benéfico-social de las cofradías fue en la asistencia en el momento de la muerte. El desarrollo de la historia de las mentalidades se ha acercado al estudio de las actitudes y comportamientos ante el trance final de la vida ${ }^{62}$, un campo en el que tuvieron un especial protagonismo las cofradías. Los estudios fueron relativamente abundantes en las décadas de los 80 y 90, referidos a variados ámbitos geográficos ${ }^{63}$. Algunos trabajos inciden en el protagonismo de las cofradías en este momento trascendental en la vida de los cofrades ${ }^{64}$.

${ }_{62}$ Lourdes Mateo Bretos, «La historiografía de la muerte: trayectoria y nuevos horizontes», Manuscrits, 12 (1994), págs. 321-356. Más distante en el tiempo, Máximo García FernándEz, «Actitudes ante la muerte, religiosidad y mentalidad en la España Moderna. Revisión historiográfica», Hispania, 176 (1990), págs. 1.073-1.090.

63 Los trabajos más importantes sobre el tema son los de Fernando Martínez Gil, Actitudes ante la muerte en el Toledo de los Austrias, Toledo, Ayuntamiento de Toledo, 1984; M. a José DE LA PASCuA SÁnchez, Actitudes ante la muerte en el Cádiz de la primera mitad del siglo XVIII, Cádiz, Diputación Provincial de Cádiz,1984; Roberto J. LóPEZ, Oviedo. Muerte y religiosidad en el siglo XVIII (Un estudio de mentalidades colectivas), Oviedo, Servicio de Publicaciones del Principado de Asturias, 1985; Marion Reder Gadow, Morir en Málaga. Testamentos malagueños del siglo XVIII, Málaga, Universidad de Málaga, 1986; José A. Rivas Álvarez, Miedo y piedad: testamentos sevillanos del siglo XVIII, Sevilla, Diputación Provincial de Sevilla, 1986; Antonio Peñafiel Ramón, Testamento y buena muerte (Un estudio de mentalidades en la Murcia del siglo XVIII), Murcia, Ed. de la Academia Alfonso X El Sabio,1987; Baudilio Barreiro Mallón, «Muerte y religiosidad en las comunidades campesinas del Antiguo Régimen», en VV. AA., Homenaje a Carlos Cid, Oviedo, Universidad de Oviedo, 1989, págs. 99-117; Ofelia Rey Castelao, «La muerte en Galicia. Actitudes religiosas ante el más allá en el Antiguo Régimen», en Xavier Castro Pérez y Jesús de Juana López (coords.), Mentalidades colectivas e ideoloxías, Orense, Deputación Ourense, 1991, págs. 171-208; David González Cruz, Religiosidad y ritual de la muerte en la Huelva del Siglo de la Ilustración, Huelva, Diputación Provincial de Huelva, 1993; Máximo García Fernández, Los castellanos y la muerte. Religiosidad y comportamientos colectivos en el Antiguo Régimen, Valladolid, Junta de Castilla y León, 1996; Manuel J. de LaRa Ródenas, La muerte barroca. Ceremonia y sociabilidad funeral en Huelva durante el siglo XVII, Huelva, Universidad de Huelva, 1999; Manuel J. DE LARA Ródenas, Muerte y religiosidad en la Huelva del Barroco. Un estudio de historia de las mentalidades a través de la documentación onubense del siglo XVI, Huelva, Universidad de Huelva, 2000; Juan BERMEJo DE LA CRUZ, Actitudes ante la muerte en el Ávila del siglo XVII, Ávila, Diputación Provincial de Ávila, 2008.

64 Jesús Castellanos Guerrero, «Las cofradías de Semana Santa de Málaga ante la salud, la enfermedad y la muerte. Notas para su estudio», Jábega, 49 (1985), págs. 36-43; Anastasio Alemán IlLán, «Sociabilidad, muerte y religiosidad popular. Las cofradías de Murcia durante el siglo XVIII», en León C. Álvarez Santaló, M. Jesús Buxó y Salvador Rodríguez Becerra (coords.), La religiosidad popular, vol. II, págs. 361-383; Tomás A. Mantecón Movellán, «La organización de la ayuda mutua y el socorro de almas en el mundo rural de Cantabria durante el Antiguo Régimen. Las cofradías religiosas», Publicaciones del Instituto de Etnografía y Folklore Hoyos Sainz, 11 (1989), págs. 193-232; Juan A. Sánchez López, Muerte y Cofradías de Pasión en la Málaga del siglo XVIII (La imagen procesional del Barroco y su proyección en las mentalidades), Málaga, Diputación Provincial de Málaga, 1990; David González Cruz, «Cofradías y ritual de la muerte en la Huelva del siglo XVIII», en VV. AA., Gremios, hermandades, vol. I, págs. 189-203; Miguel L. López-Guadalupe Muñoz, «Consideraciones sobre la muerte en las cofradías de ánimas de la ciudad de Granada», en León C. Álvarez Santaló y Carmen M. ${ }^{a}$ Cremades Griñán (eds.), Mentalidad e ideología en el Antiguo Régimen. Actas de la II Reunión Científica de la Asociación Española de Historia Moderna, Murcia, Universidad de Murcia, 1993, vol. II, págs. 293-304; Marion REDER GADOW, «La solidaridad cofrade más allá de la muerte en las cofradías de la Málaga de la Ilustración», en Juan Aranda Doncel (ed.), Actas del III Congreso Nacional de Cofradías de Semana Santa, Córdoba, Cajasur, 1997, págs. 153-165; Manuel F. Matarín Guil, «Creencia popular en las Ánimas del Purgatorio en los valles de los ríos Andarax y Nacimiento», en Valeriano Sánchez Ramos y José 
Ciertas cofradías alcanzaron un alto grado de especialización, ocupándose de los entierros de ajusticiados, actos sociales de pública compasión que solían correr a cargo de hermandades de caridad y misericordia. Además de las cofradías de la Purísima Sangre de Jesucristo de Barcelona o del Corpus Christi de Granada, que se ocupaban de estos menesteres ${ }^{65}$, se han encontrado cofradías de este tipo en Zaragoza, Lorca, Soria, Antequera, Valladolid o Madrid ${ }^{66}$.

No faltaron tampoco cofradías que ejercieron la caridad sobre colectivos especialmente marginados, como el de las prostitutas; son las llamadas «rondas del pecado mortal», que se ocupaban del recogimiento de estas mujeres e intentaban su reinserción ${ }^{67}$.

Otras cofradías prestaron atención a diversos colectivos desfavorecidos, como los pobres encarcelados y los niños expósitos. Se han estudiado, al menos, las "cofradías de la cárcel" existentes en Málaga y Antequera ${ }^{68}$. Por lo que se refiere a los expósitos, fue pionero el estudio de Teófanes Egido sobre la hermandad de San José de Valladolid ${ }^{69}$, al que siguieron referencias sobre

Ruiz Fernández (coords.), Actas de las I Jornadas de Religiosidad Popular, Almería, Instituto de Estudios Almerienses, 1997, págs. 75- 90; Joaquín Rodríguez Mateos, «Bien a los muertos y utilidad para los vivos. El auxilio funerario en las cofradías de la Modernidad», en José Hernández Palomo (coord.), Enfermedad y muerte en América y Andalucía, Sevilla, CSIC, 2004, págs. 445-470; Joaquín Zambrano GonzÁlez, "Ánimas benditas del Purgatorio. Culto, cofradías y manifestaciones artísticas en la provincia de Granada», en Francisco J. Campos y Fernández de Sevilla (coord.), El mundo de los difuntos, págs. 1071-1088.

65 Arias de SaAvedra Alías y López-Guadalupe Muñoz, «Cofradías y ciudad», pág. 214 y López-GuaDALuPE Muñoz, La labor benéfico social, págs. 133-134.

${ }_{6}^{6}$ José L. Gómez Urdáñez, La Hermandad de la Sangre de Cristo de Zaragoza: caridad y ritual religioso en la pena de muerte, Zaragoza, Institución Fernando El Católico / CSIC, 1981; sobre la cofradía de la Caridad de Lorca, Domingo Munuera Rico, «Cofradías y ceremonial de ejecuciones», Áreas: revista internacional de Ciencias Sociales, 3-4 (1983), págs. 245-247; sobre la cofradía de la Piedad de Soria, Francisco Ángel Calonge García, «Reos de muerte y caridad cristiana», Hispania Sacra, LII-105 (2000), págs. 177182; para el caso antequerano, Milagros LEón VEGAS, «Un ejemplo de asistencia prestada a los condenados a muerte por la Caridad de Antequera», Jábega, 92 (2002), págs. 101-110; sobre Valladolid, Lourdes Amigo VÁzQuez, «Del patíbulo al cielo: la labor asistencial de la Cofradía de la Pasión en el Valladolid del Antiguo Régimen», en Francisco J. Campos y Fernández de Sevilla (coord.), La Iglesia española, págs. 511-542; y sobre Madrid, Jesús N. Sánchez Santos, «Cofradías y ajusticiados en Madrid», en Francisco J. Campos y Fernández de Sevilla (coord.), El mundo de los difuntos, págs. 1051-1070.

67 Antonia Morel D'Arleux, «Recogimiento y cofradías del Pecado Mortal en los siglos XVI y XVII», en Rafael Carrasco (ed.), La prostitution en Espagne. De l'époque des Rois Catholiques à la Ilè. Repúblique, Paris, Les Belles Lettres, 1994, págs. 11-135.

68 Sobre la malagueña véanse: Rafael Bejarano Pérez, «La cofradía de la cárcel (1613-1738)», Isla de Arriarán. Revista cultural y científica, 7 (1996), págs. 7-16; M. ${ }^{a}$ Carmen Gómez García y Juan M. . Martín Vergara, «La cofradía de San Juan Bautista degollado Pobres de la cárcel», Isla de Arriarán. Revista cultural y científica, 11 (1998), págs. 149-158, y M. ${ }^{a}$ Pepa LARA GARCía, «La cofradía de los pobres de la cárcel: San Juan Bautista Degollado (1591-1835)», Jábega, 104 (2014), págs. 20-23. Sobre la de Antequera: Milagros León Vegas, «La Hermandad de los pobres de la cárcel en Antequera (siglos XVI-XVII)», Baetica. Estudios de Arte, Geografía e Historia, 24 (2002), págs. 355-376.

69 Teófanes EGido LóPEz, «La cofradía de San José y los niños expósitos de Valladolid (1540-1575)», Estudios Josefinos, 53-54 (1973), págs. 77-10 y 231-259. 
las cofradías que atendían a estos niños en el estudio más general sobre los expósitos de Sevilla ${ }^{70}$. En cambio, apenas se han tratado estas cofradías en las monografías sobre este tema relativas a Andújar, Úbeda o Granada ${ }^{71}$. Sí se han abordado, en cambio, las cofradías de expósitos en Madrid y en forma de obra pía en Sepúlveda y la misma Úbeda ${ }^{72}$.

La acción benéfica de las cofradías se ocupó también de otros aspectos como la redención de cautivos, la dotación de doncellas ${ }^{73}$ o la atención a los niños huérfanos. Y tangencialmente se ligan las cofradías a la aparición de montes de piedad ${ }^{74}$.

No quedaría completa esta rápida visión sobre la tipología de las cofradías y sus desarrollos historiográficos sin aludir a un tipo peculiar de hermandades, más minoritarias, que respondían a exigencias espirituales más elevadas, nos referimos a las citadas congregaciones. Tiene en común con las cofradías asistenciales, en parte la preocupación caritativa, y sobre todo un carácter elitista; por estos motivos se distancian de las cofradías por naturaleza populares. Sus miembros solían tener más formación y un nivel de compromiso cristiano más fuerte que en el común de las cofradías, y realizaban prácticas espirituales de mayor grado de exigencia: pláticas espirituales, confesión y comunión frecuentes, etc. Dentro de estas tuvieron un significado muy especial las Escuelas de Cristo ${ }^{75}$, así como las congregaciones de seglares auspiciadas por la Compañía de Jesús ${ }^{76}$.

70 León C. Álvarez Santaló, Marginación social y mentalidad en Andalucía occidental: expósitos en Sevilla (1613-1910), Sevilla, Junta de Andalucía, 1980.

71 Enrique Gómez Martínez, Los niños expósitos en Andújar, Córdoba, Universidad de Córdoba, 1987; Adela Tarifa Fernández, Marginación, pobreza y mentalidad social en el antiguo régimen: los niños expósitos de Úbeda (1665-1788), Granada, Ayuntamiento de Granada, 1994; M. a del Prado de la Fuente Galán, Marginación y pobreza en la Granada del siglo XVIII, Granada, Universidad de Granada, 2000.

${ }_{72}$ José L. De los Reyes LeOz, «La cofradía de la Soledad. Religiosidad y beneficencia en Madrid (1567-1651)», Hispania Sacra, 79 (1987), págs. 147-184; Adela Tarifa FERnándEz, «Los niños expósitos de Úbeda (Jaén) y Sepúlveda (Segovia) en el Antiguo Régimen: las obras pías de San José y San Cristóbal», en Francisco J. Campos y Fernández de Sevilla (coord.), La Iglesia española, págs. 191-216.

73 Sobre este aspecto destaca el estudio de José Sánchez Herrero, «La acción benéfica de las cofradías durante los siglos XIV al XVII: la redención de cautivos y la dotación de doncellas para el matrimonio», en Francisco J. Campos y Fernández de Sevilla (coord.), Religiosidad popular, vol. I, págs. 163-192.

74 José López Yepes, Historia de los Montes de Piedad en España. El Monte de Piedad de Madrid en el siglo XVIII, Madrid, Confederación Española de Cajas de Ahorros, 1971; Manuel Trтos Martínez, El Monte de Piedad de Santa Rita de Casia y los orígenes del crédito en Granada, Granada, Caja General de Ahorros de Granada, 1975.

75 Manuel Moreno Valero, «La Escuela de Cristo. Su vida, organización y espiritualidad barroca», en León C. Álvarez Santaló, M. Jesús Buxó y Salvador Rodríguez Becerra (coords.), La religiosidad popular, vol. III, págs. 507-528; del mismo autor, «La Escuela de Cristo en la provincia de Córdoba», en Crónica de Córdoba y sus pueblos, XIV (2008), págs. 335-391. Especial mención merece la reciente tesis doctoral de Fermín Labarga, La Santa Escuela de Cristo, Madrid, BAC, 2013, centrada en las escuelas de Roma y sobre todo de Madrid y su proyección por toda España, así como en su expansión por los virreinatos de Nueva España y Perú.

76 Sobre las congregaciones de Granada, Miguel L. López-Guadalupe MuÑoz, «La Congregación del Espíritu Santo y otras congregaciones jesuíticas de la Granada moderna», Archivo Teológico Granadino, 55 (1992), págs. 171-212. 
Durante la Edad Moderna el fenómeno cofrade era extensivo a toda la sociedad en sus distintos estamentos y grupos, que participaban en líneas generales de una religiosidad común. No obstante, los grupos privilegiados crearon corporaciones exclusivas. La historiografía ha prestado atención a la existencia de cofradías de nobles, un fenómeno urbano y minoritario, que a finales del Antiguo Régimen tenía poco que ver con las hermandades nobiliarias medievales de carácter defensivo y militar, y respondía más bien a la intención de mostrar una posición privilegiada en la sociedad. Existe un amplio abanico de estudios sobre cofradías nobiliarias concretas en un nutrido elenco de ciudades: Málaga, Albarracín, Gijón, Sevilla... ${ }^{77}$.

También formaron los eclesiásticos cofradías exclusivas y grupales, especialmente los sacerdotes, muchas de las cuales estaban bajo la advocación de San Pedro. En este caso no respondían tanto a un mecanismo de diferenciación social, innecesario en su caso, como a las propias inquietudes espirituales y sobre todo a las necesidades asistenciales de sus miembros. Solían acoger a los sectores más modestos del clero secular ${ }^{78}$. Se ha prestado atención a las surgidas en Navarra y el País Vasco ${ }^{79}$. Recientes trabajos se han centrado en las de Palencia y Albarracín, estas últimas surgidas en el último tercio del siglo XVI, en el contexto de reorganización eclesiástica impulsada por Felipe $\mathrm{II}^{80}$. Aunque mucho menos fre-

77 Véanse, entre otros, los trabajos de Federico FERnández BASURTE, «Nobleza y cofradías: aproximación a la mentalidad nobiliar malagueña del siglo XvII», Jábega, 64 (1989), págs. 27-37; Jaime DE ANGULO Y Sáinz de Baranda, «La cofradía de caballeros de Santiago de Albarracín», Emblemata, 13 (2007), págs. 195-256; Pedro Alfonso de Diego GonzáLEz, «Un ejemplo de la dimensión religiosa de la aristocracia rural de Gijón (Asturias) en la segunda mitad del siglo XviII: el caso de la cofradía del Santísimo Sacramento de Baldornón», en Enrique Soria Mesa y Juan J. Bravo Caro (eds.), Las elites en la época moderna: La Monarquía Española, Córdoba, Universidad de Córdoba, 2009, vol. IV, págs. 129-138; M. a Matilde Hermoso MelladoDamas, «Las cofradías de los caballeros y el Concejo de Sevilla en el siglo xvi: de nobles a mercaderes», en Enrique Soria Mesa y Juan J. Bravo Caro (eds.), Las elites en la época moderna: La Monarquía Española, págs. 205-218; Esteban Mira Ceballos, «Cofradías y elites en la Carmona moderna», Isidorianum, vol. 20, 39 (2011), págs. 197-222.

78 Baudilio Barreiro Mallón, «El asociacionismo del bajo clero: la Cofradía de Todos los Santos o Venerable Congregación del clero», en Segundo L. Pérez López, Plenitudo veritatis, Santiago de Compostela, Instituto Teológico Compostelano, 2008, págs. 529-567; Marcelino MarTínez Rodríguez, «La Hermandad de San Pedro para el clero de la ciudad de Cádiz», Memoria Ecclesiae, XI (1997), págs. 593-612.

79 José Iturrate, «Cofradía del Santísimo Sacramento de los presbíteros de la Climata y Sonsierra de Navarra», Scriptorium Victoriense, vol. 49, 1-2 (2002), págs. 147-239; José IturRate, «Cofradía de la Asunción de Nuestra Señora de los Clérigos de Markínez», Scriptorium Victoriense, vol. 50, 1-4 (2003), págs. 327-390; José Iturrate, «Venerable Congregación de Sacerdotes del Señor San Pedro en el Valle de Llodio», Scriptorium Victoriense, vol. 51, 1-4 (2004), págs. 301-334.

80 Carlos Lozano Ruiz, «Un mecanismo de solidaridad en la sociedad rural palentina de la Edad Moderna: las cofradías y hermandades de clérigos», en M. a José Pérez Álvarez y Alfredo Martín García (coords.), Campo y campesinos en la España Moderna. Culturas políticas en el mundo hispano, León, FEHM, 2012, 
cuentes que las cofradías de sacerdotes, no faltó el ejemplo de alguna hermandad cuyos hermanos eran frailes y monjas, concretamente en Sevilla ${ }^{81}$.

Otros grupos sociales crearon también hermandades exclusivas. Aunque menos numerosas, existen algunos ejemplos de cofradías femeninas. Tenemos noticias de la existencia de este tipo de cofradías en Madrid, así como de la cofradía de Santa Águeda de Barcelona ${ }^{82}$. Esta última advocación fue muy frecuente en las cofradías exclusivamente femeninas, que estuvieron extendidas en algunas zonas de Castilla ${ }^{83}$. Por otra parte, un trabajo reciente ha analizado el papel de las mujeres en el conjunto de las cofradías malagueñas, mostrando un progresivo protagonismo femenino ${ }^{84}$.

Otros exóticos casos de diferenciación en cuanto a los cofrades podrían citarse, como el de una hermandad penitencial sevillana impulsada por niños, bajo la advocación del Patrocinio ${ }^{85}$. Los ejemplos de mecanismos de cerramiento ${ }^{86}$ podrían multiplicarse hasta la saciedad, sobre todo en las cofradías urbanas, ya que las rurales fueron en general mucho más abiertas, abarcando la mayoría de ellas a todos los vecinos del lugar. Hay, sin embargo, pocos estudios sobre la adscripción social de los miembros de una hermandad concreta ${ }^{87}$.

El amplio mundo de la marginación social, tan presente durante el Antiguo Régimen, especialmente en las ciudades, no fue ajeno tampoco al mundo de las cofradías. Como protagonistas, o como receptores de las ayudas cofrades, encon-

vol. II, págs. 1169-1179; José M. Latorre Ciria, «La cofradía de clérigos del obispado de Albarracín en la Edad Moderna», Rehalda, 25 (2016), págs. 75-85.

81 Carlos J. Romero Mensaque, «Una cofradía singular de frailes y monjas: la Hermandad de Jesús Nazareno y la Conmiseración de las Ánimas Benditas de Sevilla», Archivo Dominicano, 32 (2011), págs. 165-179.

82 Arias de SaAvedra Alías y López-Guadalupe Muñoz, «Cofradías y ciudad», pág. 208.

83 José A. Casquero Fernández, «La religiosidad de las mujeres: las cofradías de Santa Águeda en la diócesis de Zamora», en Francisco J. Campos y Fernández de Sevilla (coord.), Religiosidad popular, vol. I, págs. 57-80. También hay mención en obras más generales como Francisco J. Lorenzo Pinar, Fiesta religiosa y ocio en Salamanca en el siglo XVII (1600-1650), Salamanca, Universidad de Salamanca, 2010.

84 Marion Reder GADOw, «De camareras a hermanas mayores: la evolución de la presencia femenina en las cofradías de Málaga», Jábega, 104 (2014), págs. 34-49. Fue pionera en este campo Ángela Muñoz FERNÁNDEZ, «Las mujeres en los ámbitos institucionales de la religiosidad laica: las cofradías devocionales castellanas (siglos XII-XV)», en María del Mar Graña Cid y Ángela Muñoz Fernández (coords.) Religiosidad femenina: expectativas y realidades (siglos VIII-XVIII), Madrid, Laya, 1991, págs. 93-114.

85 Carlos J. Romero Mensaque, «Las actitudes religiosas de los cofrades sevillanos en las hermandades de penitencia del siglo XVIII", en VV. AA., Actas del III Congreso Nacional de Cofradías de Semana Santa, Córdoba, 1997, vol. I, págs. 177-192.

86 Claude Chauchadis, «Les modalités de la fermeture dans les confréries religieuses espagnoles (xvIe- XVIII siècles)», en VV. AA., Les sociétés fermées dans le monde ibérique (XVIe-XVIIIe siècles), Paris, CNRS, 1986, pág. 83-105.

${ }_{87}$ Matthias Litje: «Composición social de la Cofradía del Santísimo Cristo del Amor y Entrada en Jerusalén y Madre de Dios del Socorro y Señor Santiago Apóstol en la segunda mitad del siglo XvIII y la primera década del siglo XIX (1721-1807)», en VV. AA., Actas del III Congreso Nacional de Cofradías de Semana Santa, vol. I, págs. 584-589. 
tramos a pobres, gitanos, esclavos. Especial relevancia tienen en este campo las cofradías étnicas, abundantes sobre todo en la España meridional. De especial atención ha sido objeto la hermandad de negros sevillanos ${ }^{88}$; para este colectivo su pertenencia a una cofradía, además de depararle las ventajas que estas asociaciones significaban al común de los cofrades, podía revestir un testimonio de afirmación simbólica frente a las clases dominantes. Un reciente estado de la cuestión ha señalado la importancia de las cofradías étnicas, especialmente de negros, moriscos y gitanos en el conjunto del Imperio de los Habsburgo ${ }^{89}$.

Por último, no quedaría completo este breve repaso por los aspectos sociales en la composición de las cofradías sin aludir a las formadas por extranjeros, o por forasteros del mismo origen geográfico en una ciudad concreta, se trata de las cofradías de naturales como se las denominaba entonces. Hace años fue estudiado algún ejemplo existente en Granada, que agrupaba a asturianos y montañeses ${ }^{90}$; en un estudio de conjunto más reciente se ha contribuido a informar sobre las mismas especialmente en América ${ }^{91}$. No faltaron entre éstas las cofradías consideradas de nacionales ${ }^{92}$.

\section{Cofradías y fiesta: un binomio inseparable. Procesiones generales}

El culto público ha sido siempre una de las funciones esenciales del mundo cofrade. En este sentido, se constituyeron las cofradías en colaboradoras de la

88 Isidoro Moreno, La antigua hermandad de los negros de Sevilla. Etnicidad, poder y sociedad en 600 años de historia, Sevilla, Universidad de Sevilla, 1997.

89 Esteban Mira Caballos, «Cofradías étnicas en la España Moderna: una aproximación al estado de la cuestión», Hispania Sacra, vol. 66, núm. Extra 2 (2014), págs. 57-88. Escaso éxito como instrumento evangelizador de minorías tuvieron las cofradías: Amalia García Pedraza y Miguel L. López-Guadalupe Muñoz, «Cofradías y moriscos en la Granada del siglo xvi (1500-1568)», en Antonio Mestre Sanchis y Enrique Giménez López (eds.), Disidencias y exilios en la España moderna, Alicante, Caja de Ahorros del Mediterráneo / Universidad de Alicante / AEHM, 1997, págs. 377-392.

90 Miguel L. López-Guadalupe Muñoz, «La Hermandad de Nuestra Señora de Covadonga de asturianos y montañeses de Granada (1702-1810)», Chronica Nova, 18 (1990), págs. 237-266.

91 Óscar Álvarez Gila, Alberto Angulo morales y Jon A. Ramos Martínez (dirs.), Devoción, paisanaje e identidad. Las cofradías y congregaciones de naturales en España y en América (siglos XVI-XIX), Bilbao, Universidad del País Vasco, 2014. Para el mundo colonial es ya clásica la obra de Elisa LuQue Alcaide, La cofradía de Aránzazu de México (1681-1799), Pamplona, Universidad de Navarra, 1995.

92 Miguel L. López-Guadalupe Muñoz, «La Hermandad de los Franceses de Granada en el siglo XviII», en M. ${ }^{a}$ Begoña Villar García y Pilar Pezzi Cristóbal (eds.), Los extranjeros en la España Moderna, Málaga, Universidad de Málaga, 2003, vol. II, págs. 495- 510; Ana CRespo SolanA, «Nación extranjera y cofradía de mercaderes: el rostro piadoso de la integración social», M. a Begoña Villar García y Pilar Pezzi Cristóbal (eds.), Los extranjeros en la España Moderna, vol. II, págs. 175-187. Con un enfoque histórico-artístico: M. ${ }^{\circledR}$ José Castillo Utrilla, «Capillas de las Naciones en el convento de San Francisco Casa Grande de Sevilla», Laboratorio de Arte, 18 (2005), págs. 237-243. 
Iglesia para realzar las principales festividades del calendario litúrgico, aunque en la práctica festiva llegaran más lejos de lo que la doctrina y el decoro aconsejaban ${ }^{93}$. Desde el concilio de Trento esta faceta exteriorizante de las cofradías y hermandades quedó aún más potenciada y, en general, cabe hablar de una sintonía casi plena entre la Iglesia oficial y la religiosidad popular a lo largo del siglo XVII y parte del siglo XVIII. Esas prácticas se inscriben en el marco más amplio de la fiesta ${ }^{94}$.

En relación con la fiesta, cada cofradía rendía culto a su santo titular. Por tanto, el arte barroco contribuyó notablemente al auge de las cofradías y viceversa $^{95}$. El papel de la imagen sagrada, con valor taumatúrgico e incluso rodeada

93 No se ha dudado nunca de la naturaleza eclesiástica de estas asociaciones. Véase Agustín Hevia BALLINA, «Las cofradías en la vida de la Iglesia: un mundo de comunicación para la piedad y la caridad, hacia un censo de documentación de cofradías de la Iglesia en España», Memoria Ecclesiae, 1 (1990), págs. 77-108.

94 Es indispensable el recurso a obras clásicas como José A. MARAVALL, La cultura del barroco, Barcelona, Ariel, 1975; Julio CARo BARoJA, Las formas complejas de la vida religiosa (siglos XVI y XVII), Madrid, Akal, 1978; Ricardo García Cárcel, Las culturas del Siglo de Oro, Madrid, Historia16, 1989; Gloria Franco Rubio, Cultura y mentalidad en la Edad Moderna, Sevilla, Mergablum, 1998. Así como a interesantes análisis interpretativos desde la Antropología o la Historia: Isidoro Moreno Navarro, La Semana Santa de Sevilla. Conformación, mixtificación y significaciones, Sevilla, Ayuntamiento de Sevilla, 1982; Antonio Bonet Correa, Fiesta, poder y arquitectura. Aproximación al Barroco español, Madrid, Akal, 1990; Pedro Gómez García (ed.), Fiesta y religión en la cultura popular andaluza, Granada, Universidad de Granada, 1992: Uwe Schultz (dir.). La fiesta. Una historia cultural desde la Antigüedad hasta nuestros días, Madrid, Alianza Editorial, 1993; José Hurtado Sánchez (ed.), Nuevos aspectos de la religiosidad sevillana: fiesta, imagen, sociedad, Sevilla, Ayuntamiento de Sevilla, 2002; Salvador Rodrícuez BEcErra, Las fiestas de Andalucía, Sevilla, Editoriales Andaluzas Unidas, 1985; Salvador Rodríguez Becerra, Religión y fiesta. Antropología de las creencias y rituales en Andalucía, Sevilla, Signatura, 2000; Miguel Á. Ladero Quesada, Las fiestas en la cultura medieval, Barcelona, Areté, 2004; M. ${ }^{a}$ Isabel Jiménez Morales y Amparo Quiles FAz, Fiestas andaluzas. Antología de textos costumbristas, Sevilla, Renacimiento, 2008. Varios ejemplos de fiestas andaluzas en Antonio F. Fernández OrtegA, «Festividades y conmemoraciones religiosas en la diócesis de Almería a partir del Sínodo diocesano de 1635», Chronica Nova, 11 (1980), págs. 99-108; Lorenzo Pérez del Campo y Francisco J. Quintana Toret, Fiestas barrocas en Málaga. Arte efímero e ideología en el siglo xVIII, Málaga, Diputación Provincial de Málaga, 1985; Demetrio Brisset MarTín, «Los votos públicos. Análisis de las fiestas de Granada (4)», Gazeta de Antropología, 4 (1986), págs. 9-14; Federico Fernández BASurTe, «El Concejo y las fiestas de la Inmaculada en Málaga. 1640», Espacio, Tiempo y Forma, 7 (1994), págs. 195-210; Antonio L. CoRTÉs PEÑA, «Entre la religiosidad popular y la institucional. Las rogativas en la España moderna», Hispania, 191 (1995), págs. 1027-1042; Andrés SARrí́ Muñoz, Religiosidad y política. Celebraciones públicas en la Málaga del siglo XVIII, Málaga, Editorial Sarriá, 1996; Francisco Tristán GARCíA, «Las fiestas oficiales en la Baza del siglo Xvi», en Antonio L. Cortés Peña, Miguel L. López-Guadalupe Muñoz y Antonio Lara Ramos (eds.), Iglesia y Sociedad en el Reino de Granada (ss. XVI-XVIII), Granada, Universidad, 2003, págs. 389-410.

95 Bonet Correa, Fiesta, poder y arquitectura; Reyes Escalera Pérez, La imagen de la sociedad barroca andaluza. Estudio simbólico de las decoraciones efímeras en la fiesta altoandaluza. Siglos XVII y XVIII, Málaga, Universidad de Málaga, 1994; M. ${ }^{a}$ José Cuesta García de Leonardo, Fiesta y arquitectura efímera en la Granada del siglo XVIII, Granada, 1995; José J. García Bernal, El fasto público en la España de los Austrias, Sevilla, Universidad de Sevilla, 2006 (que habla de una civilización de procesiones). Aspectos artísticos con enfoque histórico en: Roberto J. LóPEz, «Las cofradías asturianas y el arte en el siglo XVIII», Boletín del Instituto de Estudios Asturianos, 45-137 (1991), págs. 307-322; Esther Fernández DE PAZ, «La influencia de la 
de un halo sobrenatural en cuanto a apariciones, leyendas y milagros se refiere ${ }^{96}$, conformó una forma de ser tan arraigada que la impronta barroca perdura hasta el día de hoy en la preferencia del gusto cofrade. Ciertamente fue entonces cuando las cofradías vivieron su edad de oro y sus manifestaciones exteriores alcanzaron una cima casi inigualable.

Entra entonces en juego la procesión, una manifestación pública de culto de amplia aceptación, como se desprende de los gastos que a ello se dedican y de la presencia masiva de un público fie $\mathrm{l}^{97}$. Por tanto, a la hora de abundar en las prácticas cofrades, las funciones de iglesia, dotadas también de la pompa barroca, han quedado relegadas ante la indudable atracción de actos realizados fuera del templo, en una clara estrategia de sacralización de espacios que la misma Iglesia alentó y que las cofradías aceptaron y extendieron sin tasa.

Los modelos procesionales son variados y en gran medida se adscriben a las tipologías confraternales ya señaladas. Además, estas manifestaciones públicas, que acabaron teniendo un inequívoco sentido identitario en términos de representación y pertenencia a la comunidad ${ }^{98}$, tienen características propias en el ámbito urbano y en el rural. En este segundo caso, destacan no sólo por la modestia de algunas manifestaciones, en lo que a presencia humana, ornato artístico e inversión pecuniaria se refiere, sino también por reflejar una sociabilidad propia ${ }^{99}$. Es el ámbito propicio para la corta distancia, la cercanía vecinal y la posibilidad de brillar a nivel local. Muchas de las fiestas de la España rural eran organizadas y costeadas por mayordomos; éstos fueron una pieza clave, incluso en los casos en que estaba constituida una cofradía. Además la vincu-

Contrarreforma en la configuración de la Semana Santa andaluza», en Religión y Cultura, Sevilla, Consejería de Cultura de la Junta de Andalucía/Fundación Machado, 1999, vol. II, págs. 493-505, o Miguel L. LópezGuAdalupe Muñoz, «Piedad desbordante y naturalismo artístico en la Granada de entre siglos: el camino hacia el Barroco», en Lázaro Gila Medina (coord.), La Escultura del primer Naturalismo en Andalucía e Hispanoamérica (1580-1625), Madrid, Arco Libros, 2010, págs. 57-74.

96 El ascenso devocional de una imagen junto al esplendor artístico puede constatarse en Miguel L. y Juan J. López-Guadalupe Muñoz, Nuestra Señora de las Angustias y su Hermandad en la época moderna. Notas de Historia y Arte, Granada, Comares, 1996.

97 Miguel L. López-Guadalupe Muñoz, «Una religiosidad con diversidad de cultos: fiesta y procesión en las cofradías de Granada, siglos XVI al XVIII», en Rafael Castañeda García y Rosa Alicia Pérez Luque (coords.), Entre la solemnidad y el regocijo. Fiestas, devociones y religiosidad en Nueva España y el mundo hispánico, Zamora (Michoacán), El Colegio de Michoacán / Centro de Investigaciones y Estudios Superiores en Antropología Social, 2015, págs. 375-419.

98 Como ejemplo la obra colectiva de Margarita TorRione (ed.), España festejante: el siglo XVIII, Málaga, Diputación Provincial de Málaga, 2000.

99 Manuel J. DE Lara Ródenas, «La sociabilidad religiosa en la Andalucía del Antiguo Régimen: hermandades y cofradías en la tierra de Huelva», Demófilo: revista de cultura tradicional de Andalucía, 23 (1997), págs. 15-42. También se aprecia en la sólida aportación de Tomás A. Mantecón MovelLán, Contrarreforma y religiosidad popular en Cantabria, Santander, Universidad de Cantabria, 1990. 
lación con los ciclos agrícolas, en definitiva la conjunción con la Naturaleza ${ }^{100}$, era más evidente en el campo que en la ciudad, aunque nunca desapareció de las devociones urbanas. Pero sobre todo el agro era el lugar idóneo para las romerías, una expresión procesional de carácter campestre que aúna en la misma realidad la celebración litúrgica, la atracción de la imagen (de santos y de la Virgen María, sobre todo), la peregrinación, la confraternización y las más arraigadas costumbres culinarias y folclóricas. La investigación en este ámbito se reduce, sin embargo y con carácter general, a grandes devociones extendidas por amplias comarcas y aun regiones ${ }^{101}$.

En el marco urbano las prácticas procesionales son básicamente más variadas y vistosas. Por supuesto, no están exentas de un cierto sesgo rural las romerías, que también las hubo en ciudades importantes, o las vías sacras, remedo más espiritual de las procesiones penitenciales de Semana Santa, aunque en ellas prima más lo individual que lo comunitario. Las vías sacras estaban bastante regladas y la orden franciscana, encargada de custodiar los Santos Lugares, ejercía una especie de monopolio, no siempre respetado, a la hora de erigir estas sendas que recreaban la pasión y muerte de Jesús. En primer lugar, necesitaban un itinerario bien medido, distanciando con rigor cada una de las catorce estaciones que componen el via crucis en su formulación más clásica. Emulando al Gólgota, cerro de la «calavera», el sentido ascensional cobraba

100 A este respecto véase el colectivo: Valeriano Sánchez Ramos (ed.), María: Regina Naturae, Congreso Mariano Nacional sobre Advocaciones de la Virgen vinculadas a la Naturaleza. Historia, arte y cultura, Berja, Centro Virgitano de Estudios Históricos / Muy Antigua, Real, Venerable e Ilustre Hermandad de Ntra. Sra. la Santísima Virgen de Gádor, 2016.

101 Sobre la romería de Ntra. Sra. del Rocío: Juan Infante Galán, Notas para la historia de la devoción a la Santísima Virgen del Rocío, Sevilla, Pontificia y Real Hermandad Matriz de Nuestra Señora del Rocío de Almonte, 1957; Manuel Á. López Taillefert, El Rocío. Una aproximación a su historia, Almonte, Pontificia, Real e Ilustre Hermandad Matriz de Nuestra Señora del Rocío, 1997; Manuel Jesús Carrasco Terriza, «Santuario del Rocío: fuentes documentales», Memoria Ecclesiae, vol. XVIII (2001), págs. 411-428, o Francisco José Mulet Ferrer, «La devoción a Nuestra Señora del Rocío de Almonte durante la Edad Moderna: una aproximación a su culto a través de la documentación testamentaria (1562-1699)», en David González Cruz (coord.), Vírgenes, Reinas y Santas. Modelos de mujer en el mundo hispánico, Huelva, Universidad de Huelva, 2007, págs. 407-415. Sobre la romería de Ntra. Sra. de la Cabeza de Andújar: VV.AA, La Virgen de la Cabeza. Iconografía y culto popular, Andújar, 1996; Rafael Frías MARín, Las cofradías y el Santuario de Nuestra Señora de la Cabeza en el siglo XVI, Marmolejo, Asociación Cultural Altozano, 1997; Enrique GómEZ MArtínez, La Virgen de la Cabeza. Leyenda, historia y actualidad, Torredonjimeno, Jabalcuz, 2002; VV. AA., Actas del I Congreso Internacional La Virgen de la Cabeza en España e Iberoamérica, Andújar, Real e Ilustre Cofradía Matriz de la Virgen de la Cabeza / Real Santuario de Nuestra Señora de la Cabeza, 2003, o José C. DE Torres, «La fiesta de Nuestra Señora de la Cabeza según Miguel de Cervantes», Boletín del Instituto de Estudios Giennenses, 193 (2006), págs. 157-170. Esa devoción a la Virgen de la Cabeza se rodea en algunos casos de fiestas de moros y cristianos: Manuel Jaramillo Cervilla, «La evolución de la religiosidad en Cúllar y nuestros pueblos. Las fiestas de moros y cristianos», Boletín del Instituto de Estudios Pedro Suárez, 18 (2005), págs. 77-94; Francisco ArRedondo Arredondo, «Religiosidad popular, espiritualidad y devoción en Zújar», Boletín del Instituto de Estudios Pedro Suárez, 18 (2005), págs. 95-126. 
un papel simbólico muy acusado en estas vías sacras ${ }^{102}$. De esta suerte, hasta las inmediaciones más escarpadas de muchas ciudades, y también pueblos, se dirigían estos caminos, jalonados de cruces o capillas, que frecuentaban las hermandades que genéricamente denominamos de vía sacra, que a veces anidaban en el seno de las más espirituales órdenes terceras ${ }^{103}$.

Al margen de estos ejemplos campestres, las procesiones urbanas solían preferir el casticismo y la centralidad de los cascos históricos, lugares privilegiados para la representación social ${ }^{104}$, como eran la plaza mayor o principal de cada localidad, las calles que ostentaban los edificios áulicos, sede de las más importantes instituciones públicas — por supuesto, las casas consistoriales de cada población, entre otras—, así como el impresionante urbanismo religioso de nuestras ciudades ${ }^{105}$. Porque, en esencia, las procesiones, a las que el abad Gordillo denomina estaciones, recorren itinerarios jalonados de paradas en lugares significativos; las parroquias, conventos y ermitas lo eran, como también esos edificios públicos. En Madrid, prototipo de escenarios ceremoniales, las procesiones religiosas alcanzaban el carácter de procesiones de corte, lo que implicaba la contemplación de esos desfiles por el rey y/o miembros de la Casa Real, de modo que se diseñaban los itinerarios en función de su paso por el patio del Palacio Real ${ }^{106}$. A menor escala, y en relación con las distintas instituciones presentes, esto ocurría en toda la geografía urbana española y americana.

Y no sólo eso. En las ciudades la repercusión de cualquier acto era mucho mayor que en las áreas rurales. También las procesiones. La presencia de la autoridad eclesiástica hacía que las cofradías estuvieran más formalizadas (casi todas gozaban de la aprobación episcopal) y que sus procesiones fueran autorizadas por la curia diocesana, particularmente por el provisor y vicario general. También a él se plegaban para obtener las oportunas licencias para demandar

102 Justamente célebre era la sevillana de la Cruz del Campo: Joaquín González Moreno, Via Crucis a la Cruz del Campo, Sevilla, Editorial Castillejo, 1992; José Roda PeÑa, El Humilladero de la Cruz del Campo y la religiosidad sevillana, Sevilla, Fundación Cruzcampo, 1999.

103 Miguel L. López-Guadalupe MuÑoz, «Una forma alternativa de piedad popular: las cofradías de vía sacra en Granada», Revista de Historia Moderna. Anales de la Universidad de Alicante, 31 (2013), págs. 11-31.

104 Federico Fernández Basurte, «La representación de la sociedad local a través de la procesión de Semana Santa (1600-1700)», en Francisco J. Campos y Fernández de Sevilla (coord.), Religiosidad popular, vol. I, págs. 627-644.

105 José L. Orozco Pardo, Christianopolis. Urbanismo y Contrarreforma en la Granada del Seiscientos, Granada, Diputación Provincial de Granada, 1985.

106 M. José DEL Río, «El simbolismo social de las procesiones de corte en el Madrid de la Edad Moderna», en VV. AA., Actas del III Congreso Nacional de Cofradías de Semana Santa, vol. I, págs. 223-235. También Elena Sánchez de Madariaga, «La eclosión de cofradías penitenciales en Madrid. Los cofrades, la disciplina pública y los entierros (1505-1639)», en VV. AA., Actas del III Congreso Nacional de Cofradías de Semana Santa, vol. I, págs. 215-216. 
públicamente con cuestaciones, que en algunos casos llegaron a constituir el sostén económico esencial de la corporación. Por supuesto, la autoridad eclesiástica participaba en las procesiones, bien sea el clero parroquial o el regular, y a menudo el propio prelado y el cabildo catedralicio, allí donde lo había.

Era un elemento indispensable si admitimos el carácter eclesial que tuvieron desde sus orígenes las cofradías y hermandades y que el propio clero se aprestó a subrayar. Sobre ese modelo, los sectores sociales de cada localidad se implicaban también en las prácticas procesionales. Bien conocido es el caso de la procesión general —y litúrgica- del Corpus Christi ${ }^{107}$. En ella no sólo participaban todas las autoridades de la ciudad ${ }^{108}$, sin descartar pleitos por cuestiones de etiqueta, precedencia y visibilidad social ${ }^{109}$, sino también incluso el conjunto de las clases urbanas y en particular el mundo gremial. Su participación era esencial en los cortejos y en el adorno de calles y plazas, lugares emblemáticos que se enmascaraban «a lo divino» para el paso del Santísimo Sacramento. Esa presencia gremial debió estar en los mismos orígenes de las solemnes procesiones eucarísticas —y también de otras procesiones «generales»-, aunque con el paso del tiempo acabaría suplantada por la asistencia de las hermandades sacramentales.

107 Son algunos estudios en concreto para el caso andaluz: José Bellver Cano, El Corpus en Granada (Evocación de sus fiestas). Granada, Lib. de Fernando Fe, s. a.; Francisco de Paula Valladar, Estudio histórico-crítico de las fiestas del Corpus en Granada, Granada, Imprenta de La Lealtad, 1886; Miguel GARRIDo Atienza, Antiguallas granadinas. Las fiestas del Corpus, Granada, Imprenta de D. José López Guevara, 1889 (ed. facsímil, Universidad de Granada, 1990); Vicente Lleó Cañal, Fiesta grande: el Corpus Christi en la historia de Sevilla, Sevilla, Ayuntamiento de Sevilla, 1980; Francisco J. Quintana Toret, «El culto eucarístico en Málaga. Ideología y mentalidad social en el siglo XVII», Jábega, 51(1986), págs. 25-33; Pedro GAN GimÉNEz, «En torno al Corpus granadino del siglo XVII», Chronica Nova, 17 (1989), págs. 91-130; Pilar Yвáñez WoRBoys, «La fiesta del Corpus en la Málaga de principios del siglo XvI», en Antonio L. Cortés Peña y Miguel L. López-Guadalupe Muñoz (eds.), Estudios sobre Iglesia y Sociedad en Andalucía en la Edad Moderna, págs. 377-386; Soledad Gómez navarro, «La eucaristía en el corazón del siglo xvi», Hispania Sacra, 118 (2006), págs. 489-515; Marion REDER GADOw, «Tradición e innovación en la procesión del Corpus Christi malagueña en la época de los Borbones», en Margarita Torrione (ed.), España festejante, págs. 63-73; Rafael VÁzQUEZ LESMES, «Episcopado y cabildo cordobeses y su devoción a la Eucaristía, siglos XVII-XVIII», en VV. AA., Religiosidad y ceremonias en torno a la Eucaristía, San Lorenzo de El Escorial, Ediciones Escurialenses, 2003, vol. I, págs. 335-350; Rafael Díaz Sánchez y José A. Romero Pérez, «La fiesta del Corpus en la Córdoba del siglo XVII y comienzos del XIX», en VV. AA., Actas del II Congreso de Historia de Andalucía. Andalucía Contemporánea, Córdoba, 2003, vol. IV, págs. 51-61, y Rafael Díaz Sánchez y José A. Romero Pérez, "La fiesta del Corpus en la Córdoba del siglo XVIII», en Poder y cultura festiva en la Andalucía Moderna, Córdoba, Universidad de Córdoba, 2006, págs. 175-194.

108 Miguel L. López-Guadalupe Muñoz, «Cofradías urbanas y acción municipal en la Granada Moderna», en Antonio L. Cortés Peña (ed.), Poder civil, Iglesia y Sociedad en la Edad Moderna, Granada, Editorial Universidad de Granada, 2006, págs. 91-111.

109 Al respecto, Sarriá Muñoz, Religiosidad y política; Miguel L. López-Guadalupe Muñoz, «Ver y ser vistos. Elites granadinas en las manifestaciones populares de piedad», en Enrique Soria Mesa y Juan J. Bravo Caro (eds.), Las elites en la época moderna, vol. 4, págs. 281-297. 
Por debajo de una procesión de rango superior como es la del Corpus Christi, menudearon iniciativas procesionales de todo tipo. Por cerrar el ámbito eucarístico, conviene mencionar las procesiones del santo viático, manifestación genuina de la hermandad sacramental de cada parroquia. Su esencia era idéntica a la procesión del Cuerpo de Cristo — por adorar la Eucaristía—, su pompa no: en la práctica se trataba de llevar a los enfermos y moribundos el sacramento eucarístico. Era una tradición arraigada en España desde época medieval, que también en el Barroco alcanzó un esplendor inusitado, pues al sacerdote y al sacristán solían acompañar miembros de la cofradía sacramental, con velas encendidas e incluso portando el palio; no tardaron en servirse de palanquines o de carruajes para dignificar este menester. Muchas parroquias acabaron realizando por su distrito una procesión anual fija de estas características que remedaba a la del Corpus.

Festejando a Cristo, a María y a los santos

Por supuesto, las procesiones de Semana Santa o estaciones de penitencia $y$ sangre, propias de las cofradías penitenciales ${ }^{110}$, acapararon la atención del público desde su mismo nacimiento. Sin duda, existieron con anterioridad prácticas devocionales en Semana Santa, ora reducidas a cortejos devotos, ora herederas de la rica tradición medieval del teatro sacro, del que todavía perdurarían en época moderna ceremonias como el «desenclavamiento». Pero será una vez rebasado el primer tercio del Quinientos cuando proliferen estas procesiones que se han perpetuado, con distinta organización, a lo largo de los siglos. Y la historiografía clásica no les dio la espalda ${ }^{111}$, como tampoco las ignoró la perspicaz mirada de los viajeros extranjeros ${ }^{112}$.

La expresión más genuina de estas procesiones es el cortejo de disciplinantes. Hay un consenso generalizado sobre su cabal vinculación con las cofradías

110 Juan Aranda Doncel, «Cofradías penitenciales y Semana Santa en la Andalucía del siglo XvIII. Del auge de la etapa barroca a la crisis de la Ilustración», en Margarita Torrione (ed.), España festejante, págs. 105-116.

111 Por ejemplo, Félix GonZÁLEZ de León, Historia crítica y descriptiva de las cofradías de penitencia, sangre y luz fundadas en la ciudad de Sevilla, Sevilla, Ediciones Giralda, 1852 (ed. facsímil, 1994); José Bermejo Y Carballo, Glorias religiosas de Sevilla o noticia histórico descriptiva de todas las cofradías de penitencia, sangre y luz fundadas en esta ciudad, Sevilla, Imp. y Librería de El Salvador, 1882; Andrés Llordén Simón y Sebastián Souvirón Utrera, Historia documental de las cofradías y hermandades de pasión en la ciudad de Málaga, Málaga, Talleres Gráficos La Española, 1969, o Fernando dE Artacho y Pérez Blázquez, Manuscrito sevillano. Crónica general de cofradías, festejos y hechos curiosos [...] entre 1717 y 1775 [...], Sevilla, Guadalquivir, 1997.

112 Verónica Gijón Jiménez, «Una mirada sobre la Semana Santa en España a través de los viajeros extranjeros de la Edad Moderna», en José A. Peinado Guzmán y M. a del Amor Rodríguez Miranda (coords.), Meditaciones en torno a la devoción popular, Granada, Asociación Hurtado Izquierdo, 2016, págs. 173-193. 
de la Vera Cruz, lo que implicaba el aliento de la popular orden franciscana ${ }^{113}$. Sin duda, hubo experiencias penitenciales al margen de la Vera Cruz ${ }^{114}$, pero ésta se lleva la palma en la forma de las procesiones de Semana Santa. La suya tenía lugar en el núcleo de los días santos, en concreto en la noche del Jueves Santo y madrugada del Viernes. La imagen sagrada tiene poca relevancia en un principio, si acaso un crucifijo en manos del sacerdote, después alguna imagen de Jesús y de María. Lo realmente importante eran los disciplinantes anónimos de blanca túnica que flagelándose expresaban un rito penitencial individual que a la vez adquiría el carácter de catarsis colectiva.

Esta fue la esencia de la Semana Santa procesional, extendida ya por toda España antes incluso de la celebración del concilio de Trento, lo que despertaba la suspicacia de algunos teólogos y obispos, como el de Guadix, que en fecha temprana trató de atajar los excesos derivados de estas procesiones «de sangre». Aun así, el modelo tuvo un éxito rotundo y el clima postridentino no hizo más que potenciar esta práctica procesional ${ }^{115}$. Las cofradías de este tipo afloraron por doquier desde mediados del siglo XVI, fueron ocupando el Jueves y el Viernes Santo, después también algunos días precedentes, surgieron al amparo de casi todas las órdenes mendicantes y también en parroquias, multiplicaron, en fin, las advocaciones de la Virgen Dolorosa y los misterios de la Pasión de Cristo. La ciudad de Sevilla alcanzaba ya la cifra de cuarenta cofradías de pe-

113 José Szmolka Clares, «Los primeros tiempos de la Hermandad de la Vera Cruz de Granada», en Juan Aranda Doncel (ed.), Actas del III Congreso Nacional de Cofradías de Semana Santa, Córdoba, Cajasur, 1997, págs. 433- 451. Algunas aproximaciones son: Juan Aranda Doncel, «Cofradías y órdenes religiosas en Lucena durante los siglos XVI y XVII: los franciscanos del convento de Madre de Dios y la hermandad de la Pasión», Boletín de la Real Academia de Córdoba, 162 (2013), págs. 263- 274, o Rafael M. Pérez García, «Formas interiores y exteriores de la religión en la Baja Andalucía del Renacimiento. Espiritualidad franciscana y religiosidad popular», Hispania Sacra, 124 (2009), págs. 587-620. También hay información en algunos estudios de Manuel Peláez del Rosal (dir.), El franciscanismo: identidad y poder, Córdoba, AHEF / UNIA, 2016.

$114 \mathrm{Y}$ de otras órdenes religiosas que se sumaron al fenómeno semanasantero tempranamente: Miguel L. López-Guadalupe Muñoz, «Origen popular e impulso conventual: la Semana Santa de Granada entre los siglos XVI y XVII», en Juan Aranda Doncel (ed.), Cofradías Penitenciales y Semana Santa. Actas del Congreso Nacional, Córdoba, Diputación de Córdoba, 2012, págs. 213-236. Del mismo autor para el caso de los dominicos «Cofradías y devociones populares en el convento de Santa Cruz la Real de Granada», en Revista de Humanidades, 27 (2016), págs. 139-161.

115 Es probable que conociera un temprano declive en determinados lugares: Milagros León VeGAS, «Entre el misticismo y la aberración. Declive de los flagelantes en Antequera (siglo XVI)», Baetica, 31 (2009), págs. 381-397. En realidad, siempre planeó sobre esta práctica la sospecha: Tomás A. Mantecón MovelLán, «La cofradía de la Vera Cruz y la proscripción de la flagelación pública en la España Moderna», en José A. Casquero Fernández (coord.), IV Congreso Internacional de Hermandades y Cofradías de la Santa Vera Cruz, Zamora, Cofradía de la Santa Vera Cruz de Zamora, 2009, págs. 545-568. Muy célebre es su representación pictórica: Alfonso Rodríguez G. de Ceballos, «La procesión de disciplinantes de la Academia de Bellas Artes de San Fernando. Goya y la religiosidad popular», Anales de Historia del Arte, extra 1 (2008), págs. 389-406. Aunque esta práctica tenía una tradición ciertamente larga: Patrick Vandermeersch, Carne de la Pasión; flagelantes y disciplinantes. Contexto histórico-psicológico, Madrid, Trotta, 2004. 
nitencia al concluir esa centuria ${ }^{116}$. La barroquización de estas procesiones fue evidente y desde la década de 1580 la eclosión imaginera constituye un proceso imparable y característico de nuestro país. Comienza por entonces la costumbre de vestir las imágenes sagradas de la Pasión para darles mayor vivacidad; era la senda artística del naturalismo.

También el modelo procesional de Semana Santa se fue diversificando. El último cuarto del siglo XVI conoce la aparición de las cofradías de Jesús Nazareno, que más allá de su advocación específica (aunque siempre con la representación de Jesús cargado con la Cruz), ofrecen un modelo alternativo a la procesión de disciplinantes. Hay en él una imitación del sufrimiento de Cristo, pero no cruenta: los cofrades siguen la imagen de Jesús y cargan, como él, la cruz. Por lo general estos cofrades visten túnicas moradas y su salida procesional se ubica en el amanecer del Viernes Santo. El Carmelo descalzo se liga a este modelo ${ }^{117}$, pero no faltó el aliento de otras órdenes religiosas.

Por entonces, si bien cofradías del Entierro de Cristo ya existían desde tiempo atrás, éstas van a ir adquiriendo una impronta muy particular: la procesión en forma de entierro. Se trata de una trasposición de solemnes funerales, regios o de personajes notables, a la que asiste toda la sociedad local debidamente ordenada. Además ciertas connotaciones eucarísticas se fueron imponiendo sobre este cortejo a lo largo del Seiscientos, como el hecho de que fueran

116 Sólo a título de ejemplo para el caso andaluz: Rafael OrTEga y SAGrisTa, «Historia de las Cofradías de Pasión y de sus procesiones de Semana Santa en la ciudad de Jaén (siglos XvI al xx)», Boletín del Instituto de Estudios Giennenses, 10 (1956), págs. 9-72; VV. AA., Semana Santa en Jaén, Jaén, Monte de Piedad y Caja de Ahorros de Córdoba, 1984; Elías de Mateo Avilés (coord.), La Semana Santa malagueña a través de su historia, Málaga, Arguval, 1987; Francisco J. Fernández Segura y Santiago Pérez López, Semana Santa en Guadix: aspectos históricos, Guadix, Federación de Cofradías de Semana Santa, 1987; José Szmolka Clares, «Historia de la Semana Santa granadina desde sus orígenes al siglo XVII», en VV. AA., Semana Santa en Granada, Sevilla, Gemisa, 1990, vol. I, págs. 15-91; Miguel L. López-Guadalupe Muñoz, «Historia de la Semana Santa granadina desde el siglo XVIII hasta nuestros días», en VV. AA., Semana Santa en Granada, vol. I, págs. 93-243; VV. AA., Semana Santa en los pueblos cordobeses, Córdoba, Caja Provincial de Ahorros de Córdoba, 1990; VV. AA., Semana Santa en la provincia de Málaga, Málaga, Obispado de Málaga, 1994; Miguel L. y Juan J. López-Guadalupe Muñoz, Historia viva de la Semana Santa de Granada. Arte y devoción, Granada, Editorial Universidad de Granada, 2002; José Sánchez Herrero, La Semana Santa de Sevilla. Madrid, Sílex Ediciones, 2003; Archivos y fondos documentales para la historia de la Semana Santa en Andalucía, Málaga, Ayuntamiento de Málaga, 2003. Para toda Andalucía, Isidoro Moreno Navarro (coord.), La Semana Santa como Patrimonio Cultural de Andalucía, vol. I de la colección Artes y Artesanías de la Semana Santa Andaluza, Sevilla, Ed. Tartessos, 2006. Y de gran interés comparativo resultan las síntesis de Juan Aranda Doncel, Breve historia de la Semana Santa de Córdoba, Málaga, Sarriá, 2001; Rafael Rodríguez PuEnte, Breve historia de la Semana Santa de Almería, Málaga, Sarriá, 2002; Miguel L. López-Guadalupe Muñoz, Breve Historia de la Semana Santa de Granada, Málaga, Sarriá, 2003; José Jiménez Guerrero, Breve historia de la Semana Santa de Málaga, Málaga, Sarriá, 2003; Carlos J. Romero Mensaque y José M. Domínguez León, Breve historia de la Semana Santa de Sevilla, Málaga, Sarriá, 2003.

117 José Szmolka Clares, «La religiosidad popular granadina y San Juan de la Cruz», en VV. AA, Congreso IV Centenario de la muerte de San Juan de la Cruz, Jaén, UNED, 1992, págs. 187-201. 
sacerdotes los portadores de la imagen yacente de Cristo o que reverenciaran a esta con un palio de respeto. Las vestimentas negras de los cofrades del Entierro de Cristo, que suele acompañarse de la Soledad de María, inundaban las calles en la noche del Viernes Santo. Esta procesión acabó convertida a finales de la época moderna en procesión oficial, y en ocasiones única, en muchas ciudades españolas, situación que dominaría en buena parte de la Semana Santa decimonónica.

Lo más destacado, empero, más que estas alternativas procesionales, es la senda de barroquización que comenzó a transitar la Semana Santa hispana y que es ya muy evidente en la plenitud del siglo XVII. Viejas y nuevas cofradías enriquecieron sus cortejos con la bella imaginería barroca de nuestras escuelas escultóricas $^{118}$, representaciones cargadas de realismo y naturalismo, subrayando la humanidad del sufrimiento de Cristo y el dolor de la Virgen María. Se presentaban en la calle en «pasos» paulatinamente de mayores proporciones y ornamentación. Se completaba el cortejo procesional con profusión de insignias, en las que alcanzó el bordado una justa relevancia. Más característica fue la presencia de elementos figurativos que aparecen como fruto de la teatralidad del Barroco y de su intencionalidad de sorprender, aunque a veces en menoscabo del decoro. Es el caso de los soldados romanos («armaos»), la representación de apóstoles y personajes bíblicos, la introducción de chías (expresivas del dolor, en tierras granadinas), de sibilas, de elementos simbólicos (como el demonio, la muerte, los vicios y virtudes), la presencia militar y el acompañamiento musical, especialmente de música coral. La procesión barroca de Semana Santa se vio cargada de un complejo simbolismo que los cofrades repetían con precisión ritual. Su presencia se rastrea con vigor durante el siglo XVIII, lo que despertó no pocas críticas y restricciones por parte de la autoridad eclesiástica y, desde luego, de los gobiernos ilustrados ${ }^{119}$.

Las procesiones de la Virgen María adquirieron una magnitud extrema en la España moderna. Desde sencillas procesiones en pueblos y lugares hasta solemnes desfiles que empezaban a adoptar un carácter patronal. La reciente adscripción de estas manifestaciones a la rúbrica de procesiones «de gloria» no refleja exactamente la rica realidad de tiempos pasados ${ }^{120}$. Las principales fiestas de la

118 Miguel L. López-Guadalupe Muñoz, «La Estación de Penitencia en la Granada del siglo XviII de la disciplina pública a la exaltación de la imagen», en Juan Aranda Doncel (ed.), Actas del III Congreso Nacional de Cofradías de Semana Santa, págs. 120- 135.

119 Muy ilustrativo resulta Juan Aranda Doncel, «Ilustración y religiosidad popular en la diócesis de Córdoba. La actitud de los obispos frente a las celebraciones de la Semana Santa (1743-1820)», en VV. AA., Actas del Primer Congreso Nacional de Cofradías de Semana Santa, págs. 305-318.

120 Para el caso sevillano, Manuel Serrano y Ortega, Glorias sevillanas. Noticia histórica de la devoción y culto que la muy noble y muy leal ciudad de Sevilla ha profesado a la Inmaculada Concepción de la Vir- 
Virgen (Asunción o Virgen de Agosto, Natividad de María, Concepción, Purificación o Candelaria, Encarnación, Virgen del Rosario, Virgen del Carmen, etc.) tuvieron en las grandes ciudades el refrendo popular en forma de actos cofrades. No era sólo cuestión de calendario, pues en realidad ya en pleno siglo XVII, e incluso antes, se observa la distinción preferencial de determinadas imágenes marianas que encarnan una devoción colectiva y, por tanto, protagonizan procesiones multitudinarias en determinadas festividades, con ocasión de rogativas y votos formulados en caso de calamidades colectivas (epidemias, plagas, sequías, e incluso seísmos ${ }^{121}$ ), dedicaciones de templos y otras ocasiones extraordinarias.

Además, algunas modalidades confraternales marianas se hicieron justamente célebres. Así ocurre con las cofradías concepcionistas, en general aquéllas que veneraban y defendían la inmaculada concepción de María como causa nacional (pues aún tardaría la Santa Sede en proclamar ese dogma). El mundo cofradiero en su conjunto participó en la defensa de esta creencia, pero esas corporaciones marianas nacieron expresamente para rendirle culto y cantar en su honor himnos solemnes y coplas populares por las calles. También muy específicas fueron las cofradías rosarianas que, impulsadas por la orden dominica, encontraron una inusitada proyección por toda la geografía hispana, desde las grandes ciudades hasta los pueblos más diminutos. Su finalidad era el rezo del rosario, bien en el templo o bien en la calle; en este segundo caso derivaron hacia las llamadas congregaciones rosarianas, que desde finales del siglo XVII fueron llenando con sus rezos y canciones las calles de numerosas localidades, dando lugar a un rico folclore religioso mantenido en parte hasta hoy, mientras hacían proliferar rosarios callejeros a todas las horas del día y de la noche, si ben fueron los «rosarios de la aurora» los que contaron con mayor originalidad ${ }^{122}$.

En general órdenes terceras (Carmen, Dolores o Servitas...), cofradías gremiales y diversidad de hermandades devocionales concurrieron con su esfuerzo y fervor al esplendor de las cofradías marianas que radicaron tanto en conventos

gen María..., s. 1. Imp. de E. Rasco, 1893; Lucas F. Mateo Seco, Piedad popular mariana en Sevilla durante los siglos XVII y XVIII, Salamanca, 1983; Alfonso Braojos Garrido (coord.), Otras fiestas de Sevilla. Cruces de mayo, Corpus, Virgen de los Reyes, Sevilla, Ayuntamiento de Sevilla, 1997.

121 Por ejemplo, respecto a seísmos: Antonio González Cantero, Noticias sevillanas del siglo XVIII. La Virgen del Amparo y el terremoto de Lisboa de 1755, Sevilla, Ayuntamiento de Sevilla, 2005; Salvador HernáNdez González y Julio Mayo Rodríguez, Utrera y el terremoto de 1755, Utrera, Ayuntamiento de Utrera, 2005; José J. García Bernal y Miguel L. López-Guadalupe Muñoz, «El temblor de 1680, entre tradición retórica y pedagogía moderna», Baetica, 32 (2010), págs. 339-353.

122 Manuel Peláez del Rosal (dir. y ed.), Congreso Nacional Las Cofradías y Hermandades de Nuestra Señora de la Aurora: Historia, Cultura y Tradición, Priego de Córdoba, Asociación de Amigos de Priego de Córdoba, 2016. Un caso curioso es el rosario madrileño ligado a los actores de teatro en José Subirá, El gremio de representantes españoles y la cofradía de Nuestra Señora de la Novena, Madrid, Instituto de Estudios Madrileños,1960. 
como en parroquias, determinando a la vez una topografía mariana jalonada no sólo de templos, sino también de pequeñas capillas, altares callejeros y horna$\operatorname{cinas}^{123}$.

Las procesiones con santos fueron también variadas, sin duda menos bulliciosas que las marianas y también peor conocidas; en parte, porque su importancia parece haber remitido en los últimos tiempos ${ }^{124}$. Santos y santas fueron titulares de cofradías gremiales, que les rendían culto en su festividad correspondiente ${ }^{125}$. Pero destacan también las de carácter conventual, sobre todos en honor de santos/as relacionados/as con las respectivas órdenes religiosas, y las sencillamente devocionales, por ejemplo ligadas en cada parroquia a su santo titular. En muchas localidades han dado lugar a peculiaridades muy curiosas y, en general, contribuyeron a solemnizar las festividades del santoral y a desplegar determinados rituales de protección de la comunidad. Merecen un mayor esfuerzo investigador del que han suscitado hasta la fecha.

La proyección externa del mundo cofradiero no se agota con esas categorías enumeradas, aunque sin duda fueron las más sobresalientes. Hay que considerar los actos y cultos de las hermandades de ánimas, muy extendidas por las parroquias para fomentar las misas por los fallecidos y rara vez con proyección procesional $^{126}$, más allá de la visita y el responso en los cementerios parroquiales o en los improvisados «carneros».

\section{Cofradías pleitistas: la defensa de la propia autonomía}

Puede sonar a tópico, no carente de verdad, el afán por pleitear que rodea al mundo cofrade en su conjunto. De hecho, buena parte de la documentación

${ }^{123}$ Eva Fernández de Paz, Religiosidad popular sevillana a través de los retablos de culto callejero, Sevilla, Diputación Provincial de Sevilla, 1987.

124 Marion Reder Gadow, «Una fiesta para el recuerdo: las fiestas de San Ciriaco y Santa Paula, patronos de Málaga», en Alberto Romero Ferrer (coord.), VI Encuentro de la Ilustración al Romanticismo. Juego, Fiesta y Transgresión, 1750-1850, Cádiz, Universidad de Cádiz, 1995, págs. 351-364. En general, León C. Álvarez Santaló, «Santos, patronos y santuarios», Demófilo: Revista de Cultura Tradicional, 16 (1995), págs. 81- 106, y José Jaime García Bernal, «Fiestas en honor de los santos», en Antonio L. Cortés Peña y Miguel L. López-Guadalupe (eds.), Estudios sobre Iglesia y Sociedad en Andalucía en la Edad Moderna, págs. 319-339.

125 Roberto J. LóPEz, «Gremios y cofradías en las fiestas públicas del Noroeste peninsular durante la Edad Moderna», en VV. AA., Gremios, hermandades, vol. II, págs. 9-26; Paloma Manzanos Arreal, «Manifestaciones religioso-festivas de las vecindades, gremios y cofradías en la Vitoria de la Edad Moderna», Zainak, 26 (2004), págs. 121-135.

${ }^{126}$ Aunque hay un caso, pero no de cofradía de ánimas: Pablo Antón Solé, «La procesión de los huesos celebrada por la Santa Caridad del Puerto de Santa María en el año 1758», Archivo Hispalense, 129-130 (1965), págs. 137-148. 
de archivo conservada en relación con las cofradías y hermandades tiene que ver con esa realidad litigiosa, que ha llenado de piezas procesales los archivos diocesanos y judiciales.

El pleito se concibe hoy como una realidad esencial para preservar el orden establecido en una sociedad legalmente desigual, como era la del Antiguo Régimen. Era sencillamente una válvula de escape no violenta para tensiones sociales de toda índole. Por ello, se recurría con frecuencia a la justicia y las cofradías lo hicieron sin pudor, a pesar de los costes económicos que acarreaban a menudo esos litigios ${ }^{127}$. Estos se entablaron con determinados hermanos, entre cofradías y, lo que era bastante frecuente, frente a decisiones del clero y de la jerarquía eclesiástica ${ }^{128}$.

Lo económico prima como causa de muchos de esos procesos judiciales. Se trata en gran medida de incumplimientos por parte de los hermanos, que en muchos casos implicaban la apropiación de fondos colectivos: mayordomos que no entregaban en regla el inventario de bienes, cargos salientes que dejaban «alcanzada» la hermandad sin saldar el déficit de su bolsillo, ejecución de gastos excesivos que no todos los hermanos estaban dispuestos a afrontar, enajenación de bienes sin la autorización correspondiente, mala gestión de las rentas fijas de la cofradía ${ }^{129}$, apropiación particular de lo recaudado por vía

127 Un ejemplo en la historiografía temprana es Fernando JiméNEZ DE GREGoRio, «Incidentes en algunos gremios y cofradías de Murcia a finales del siglo XVIII », Anales de la Universidad de Murcia, 1950-1951, págs. 217-242. Más reciente es Miguel L. López-Guadalupe Muñoz, «Litigar y sobresalir. Cofradías y justicia eclesiástica en Granada (1665-1700)», en Antonio Jiménez Estrella y Julián J. Lozano Navarro (eds.), Actas de la XI Reunión Científica de la Fundación Española de Historia Moderna. Comunicaciones, Granada, Editorial Universidad de Granada, 2012, vol. II, págs. 174-187.

128 Con detalle y amplia perspectiva: Carlos J. Romero Mensaque, Pleitos y conflictos en las hermandades y cofradías de Sevilla: una aproximación histórica, Sevilla, Marcia, 2000. Hay estudios parciales, generalmente en el campo de las cofradías penitenciales, como Juan A. SÁnchez LóPEZ «Conflictividad jurídica y presión institucional sobre las hermandades de Málaga a finales del Antiguo Régimen», en León C. Álvarez Santaló y Carmen M. ${ }^{a}$ Cremades Griñán (coords.), Mentalidad e Ideología en el Antiguo Régimen, Murcia, 1993, págs. 443-460; Florián Ferrero Ferrero y Francisco J. Lorenzo Pinar, «La conflictividad en torno a las cofradías zamoranas de Semana Santa en la Edad Moderna», en VV. AA., Actas del III Congreso Nacional de Cofradías de Semana Santa. I. Historia, Córdoba, Cajasur, 1997, págs. 161-175; Ángel J. Moreno Prieto, «Conflictos en torno a las cofradías de la Vera Cruz en Castilla y León durante el Antiguo Régimen», en José A. Casquero Fernández (coord.), IV Congreso Internacional de Hermandades y Cofradías de la Santa Vera Cruz, Zamora, Cofradía de la Santa Vera Cruz de Zamora, 2009, págs. 651-687, o Juan Aranda Doncel, «Conflictos y tensiones en las cofradías penitenciales cordobesas durante los siglos XVI al XIX», en Juan Aranda Doncel (coord.), Cofradías penitenciales y Semana Santa, Córdoba, Diputación Provincial de Córdoba, 2015, págs. 115-172.

129 Apenas hay estudios en este sentido: Miguel L. LÓPEZ-Guadalupe Muñoz, «Las cofradías y hermandades de la ciudad de Granada en el Catastro de Ensenada», Revista del Centro de Estudios Históricos de Granada y su Reino, 5 (1991), págs. 205-238, y Miguel L. López-Guadalupe Muñoz, «Aproximación a los ingresos de las cofradías de la ciudad de Granada a través del Catastro de Ensenada», en II Congreso de Historia de Andalucía. Andalucía Moderna II, Córdoba, Junta de Andalucía / Cajasur, 1995, págs. 375-388. 
de demanda o incumplimiento de esta obligación, picaresca en la obtención de fondos con la hermandad como pretexto (venta de patentes, indulgencias, estampas o medallas), incumplimiento de los deberes de pago a proveedores y un largo etcétera. Subyace, en cualquier caso, el abuso de lo colectivo en beneficio particular.

Entre los mismos cofrades aparecen causas relacionadas con la no aceptación de los cargos para los que eran elegidos o el incumplimiento de sus obligaciones, pleitos que ponen el dedo en la llaga sobre la presión que podía significar para las familias la designación para cargos que conllevaban importantes sacrificios personales y económicos. No era fácil inhibirse del desempeño de esos cargos, considerados como una obligación social entre el vecindario. Los ilustrados denunciaron esta realidad a través de sus críticas y de sus directrices. Pendencias entre los cofrades, por cuestiones ajenas a la cofradía, también enrarecían el clima cotidiano de la misma. En las cofradías más antiguas se reconocía la autoridad moral del hermano mayor para pacificar esas disputas, a ser posible sin recurrir a los tribunales, y en cualquier caso las hermandades actuaron a nivel local —algo muy evidente en sociedades pequeñas y cerradas- como elemento de armonía social y concordia vecinal $^{130}$.

Más significativas desde el punto de vista social son las causas entabladas entre cofradías. Traslucen la rivalidad simbólica, y a veces más que simbólica, entre estas corporaciones, aspecto que se ha resaltado desde la Antropología cultural $^{131}$. La chispa saltaba por cuestiones a veces nimias, pero reveladoras de la autonomía de cada corporación y su deseo de sobresalir. Iguales en su naturaleza, eran distintas en sus formulaciones y esa distinción era motivo de orgullo, de autoafirmación. De ese modo, reproducen en su seno una mentalidad social jerárquica basada en conceptos como el privilegio o el corporativismo. Las cofradías litigaban por el orden que ocupaban en las procesiones generales y otros actos colectivos, por el uso privativo de una advocación, por la concurrencia en su distrito de demandas de otras hermandades, por la no devolución de enseres prestados, por la preferencia de paso en función de su

130 Mantecón Moveluán, Contrarreforma y religiosidad popular.

131 Basten las obras clásicas de Moreno Navarro, La Semana Santa de Sevilla; «Las hermandades andaluzas. Una aproximación desde la Antropología», en VV. AA., Cofradías y hermandades andaluzas, Granada, Editoriales Andaluzas Unidas, 1985, págs. 13-129; o «La Semana Santa: Más allá del fervor religioso», Clío, revista de Historia, 5 (2002), págs. 80-87. Y también Rafael Briones Gómez. «La Semana Santa andaluza», Gazeta de Antropología, 2 (1983), págs. 4-10, y Salvador Rodríguez BecerRa, Religión y cultura, Sevilla, Junta de Andalucía, 1999, o Salvador Rodríguez Becerra, «Nuevas perspectivas sobre la religiosidad popular o religión común de los andaluces», Gazeta de Antropología, 28 (2012), págs. 32- 41. 
antigüedad $^{132}$. Este último fue un concepto muy asumido y defendido en el marco de la sociedad local.

Por último, esa autonomía en la decisión y en la gestión provocó frecuentes roces con el estamento eclesiástico del que dependían. No todos los decretos de instancias superiores fueron bien recibidos y es frecuente constatar atisbos de resistencia y a veces de abierta confrontación ${ }^{133}$. Respetaban la dirección espiritual del clero e incluso el control que éste ejercía sobre la cofradía respectiva, pero plantaban cara a lo que consideraban injerencias, como interferir en los procesos electivos — las cofradías eran razonablemente «democráticas» en su funcionamiento frente a la rigidez jerárquica de la Iglesia—, apropiarse de rentas o limosnas que se consideraban de la cofradía, interferir e incluso anular determinados actos de culto (sobre todo procesiones, porque respecto a las funciones de iglesia el clero sacaba la correspondiente tajada económica), dirimir el uso de la capilla y otras dependencias del templo y, en definitiva, postergar a la cofradía en el diario devenir de conventos, y sobre todo parroquias, en el que ellas tenían mucho que decir. No se arredraban los cofrades ante los primeros obstáculos y, si sus arcas se lo permitían, recurrían al enmarañado juego de jurisdicciones para defender sus intereses ${ }^{134}$. No fue raro, por tanto, apelar a los tribunales reales, incluso a la nunciatura y a la justicia papal.

\section{El control ilustrado: el Expediente General de Cofradías}

Un aspecto tratado por la historiografía ocupada en las cuestiones religiosas y de mentalidades colectivas es el divorcio surgido durante el siglo XVIII entre dos formas distintas de entender la religión: la forma más extendida que se ha

132 Miguel L. López-Guadalupe Muñoz, «La Semana Santa contrarreformista: conflicto y control de las procesiones andaluzas de finales del siglo XVI», en Enrique Martínez Ruiz (dir.), Madrid, Felipe II y las ciudades de la monarquía. Las ciudades: vida y cultura, Madrid, Actas, 2000, vol. III, págs. 417-427, «Sociedad y Semana Santa en Andalucía (siglos XVI-XVIII): Orden y desorden», en VV. AA., Archivos Locales y Mundo Cofrade, Málaga, Ayuntamiento de Málaga, 2002, págs. 101-131, y Miguel L. López-Guadalupe Muñoz, «La religión en la calle. Encuentros y desencuentros en torno a la religiosidad barroca», Andalucía en la Historia, 15 (2007), págs. 30-37. También Inmaculada Arias de Saavedra Alías y Miguel L. López-Guadalupe Muñoz, «La prelación como conflicto. Cofradías y orden en el Antiguo Régimen», en Manuel Peña (ed.), La vida cotidiana en el mundo hispánico (siglos XVI-XVIII), Madrid, Abada Editores, 2012, págs. 137-158.

133 Miguel L. López-Guadalupe Muñoz, «Debate y reacción a las reformas ilustradas: maniobras legales de las cofradías a finales del siglo XvIII», Chronica Nova, 29 (2002), págs. 179-216.

134 Ejemplos en Miguel L. López-Guadalupe Muñoz, «Actitudes sociales en torno a una cofradía del siglo XVIII. El proceso contra la hermandad de la Concepción de Jerez de los Caballeros», Revista de Estudios Extremeños, XLIX (1993), págs. 425-45, y Miguel L. LóPEZ-Guadalupe MuÑoz, «Cofradías andaluzas bajo el Antiguo Régimen: jurisdicción eclesiástica y jurisdicción civil», en VV. AA., La Iglesia española en la Edad Moderna. Balance historiográfico y perspectivas, Madrid, Abada Editores, 2007, págs. 247-283. 
denominado religiosidad popular o religiosidad barroca, muy ligada al mundo de los sentimientos, apegada a la tradición y a las prácticas rituales externas, sin grandes planteamientos doctrinales ni teológicos, y una religiosidad ilustrada, mucho más minoritaria e intelectualizada, propia de las elites más cultas y de los sectores más dinámicos de la jerarquía eclesiástica, más personalizada e intimista, con una rigurosa concepción de la moral, y enemiga de prácticas que podían rayar en la superstición. El asunto ha sido tratado con solvencia en estudios de Antonio Mestre y Teófanes Egido, entre otros ${ }^{135}$. Estos cambios están en el origen de la actitud de desafección de las clases dirigentes ilustradas respecto a la religiosidad popular y a sus manifestaciones más extendidas, las cofradías, que en el reinado de Carlos III fueron sometidas a un proceso judicial dentro de un ambicioso plan de reducción.

Fruto de esta actuación el Expediente General de Cofradías del Reino, especie de foto fija del mundo cofrade en la década de los setenta del siglo XVIII, que determinó la existencia de más de 25.000 cofradías en todo el país y constituye, con todos sus problemas y limitaciones, una fuente inigualable para el estudio de la realidad cofrade. Esta magna encuesta ha sido objeto de múltiples trabajos desde distintas ópticas. Uno de sus primeros estudios lo constituyó un análisis de la fuente, a través de un pormenorizado regesto documental de los diecisiete legajos que la integran y se conservan en el Archivo Histórico Nacional ${ }^{136}$. En los años siguientes aparecieron algunas visiones generales sobre la actuación frente a las cofradías, ofrecida a través de diversos trabajos ${ }^{137}$.

Posteriormente, la concesión de un proyecto de investigación por parte de la DGICYT del Ministerio de Educación de entonces, nos permitió abordar este proceso por medio de una serie de estudios que iban desde la propuesta metodológica para utilizarlo como fuente ${ }^{138}$, al análisis de los informes de las distintas

135 Para una visión de conjunto de la religiosidad de la época véanse sobre todo: Antonio MestRE SANCHIS, «Religión y cultura en el siglo XVIII español», en La Iglesia en la España de los siglos XVII y XVIII, vol. IV de Ricardo García Villoslada (dir.), La Iglesia de España, Madrid, BAC, 1979, págs. 583-743, y Teófanes Egido López, «La religiosidad de los ilustrados», en La época de la Ilustración. I. El Estado y la cultura, vol. XXXI de Historia de España de Menéndez Pidal, Madrid, Espasa Calpe, 1987, págs. 396-437.

136 Milagrosa Romero SAmper, «El expediente general de cofradías del Archivo Histórico Nacional. Regesto documental», Hispania Sacra, 40 (1988), págs. 205-234.

137 Farid ABвAD, «La confrérie condamnée ou une spontainéité festive confisquée: un autre aspect de l'Espagne à la fin de l'ancien régime», Mélanges de la Casa de Velázquez, vol. III (1977), págs. 361-384; Miguel L. López-Guadalupe Muñoz, «Control estatal de las asociaciones de laicos (1763-1814)», en Emilio La Parra y Jesús Pradells (eds.), Iglesia, sociedad y estado en España, Francia e Italia. Siglos XVIII y XIX, Alicante, 1991, págs. 341-359; Milagrosa Romero SAmper, Las cofradías en el reformismo de Carlos III, Madrid, Fragua, 1991.

138 Inmaculada Arias de SaAvedra Alías y Miguel L. López-Guadalupe Muñoz, «El Expediente General de Cofradías. Propuestas para su estudio», en Vicente Suárez Grimón, Enrique Martínez Ruiz y Manuel Lobo Cabrera, Iglesia y sociedad en el Antiguo Régimen, Las Palmas de Gran Canaria, Universidad de Las Palmas, 1994, págs. 31-40. 
instancias que intervinieron en el mismo (arzobispos, intendentes, el fiscal del Consejo de Castilla Campomanes y su presidente, el conde de Aranda), hasta la resolución final y sus efectos ${ }^{139}$. La explotación de la información contenida en el Expediente nos sirvió también para hacer estudios sobre la implantación urbana de las cofradías en el último tercio del siglo XVIII, así como para evaluar su dimensión social ${ }^{140}$. Con la documentación procedente de esta encuesta también realizamos dos estudios pormenorizados sobre la implantación de las cofradías en dos áreas periféricas del país, de diverso carácter: Murcia y Navarra ${ }^{141}$. Otros trabajos ya la habían explotado para estudiar la implantación cofrade en la provincia de Ciudad Real o en Cantabria ${ }^{142}$.

El gran filón que constituye el Expediente General no ha sido abandonado por los estudiosos de las cofradías en los últimos años, en fechas más recientes se han seguido haciendo estudios sobre áreas concretas, utilizando las ricas posibilidades que ofrece su documentación, centrados en Badajoz, Benavente, León, Valladolid o Segovia ${ }^{143}$ y la fuente dista de estar agotada.

139 Se trata de los trabajos de Inmaculada Arias de Saavedra Alías y Miguel L. López-Guadalupe MuÑoz, «Informes de los Metropolitanos en el Expediente General de Cofradías (1769)», Publicaciones. Revista de la Escuela Universitaria de Magisterio de Melilla, 25-27 (1997), págs. 17-54; «La política ilustrada ante la religiosidad popular. Intendentes y cofradías en el reinado de Carlos III», en Pablo Fernández Albaladejo, José Martínez Millán y Virgilio Pinto Crespo (eds.),, Política, religión e Inquisición en la España Moderna. Homenaje a Joaquín Pérez Villanueva, Madrid, Universidad Autónoma de Madrid, 1996, págs. 85-105; «El conde de Aranda ante la religiosidad popular. Releyendo el informe sobre cofradías de 1773», en José A. Ferrer Benimeli, Enrique Sarasa y Eliseo Serrano (coords.), El conde de Aranda y su tiempo, Zaragoza, Diputación de Zaragoza, 2000, págs. 631-645, y «Campomanes frente a las cofradías españolas», en Dolores Mateos Dorado (ed.), Campomanes doscientos años después, Oviedo, Universidad de Oviedo / Instituto Feijoo de Estudios del Siglo XVIII, 2003, págs. 669-689. El conjunto de trabajos fue recogido, junto con otros, en $\mathrm{La}$ represión de la religiosidad popular. Crítica y acción contra las cofradías en la España del siglo XVIII, Granada, Universidad de Granada, 2002. Una reflexión más reciente de los mismos autores en «La represión de las Cofradías en el Reinado de Carlos III», Tercerol. Cuadernos de investigación, 12 (2008), págs. 75-92.

140 Arias de Saavedra Alías y López-Guadalupe Muñoz, «Cofradías y ciudad», y «Las cofradías y su dimensión social».

141 Inmaculada Arias de SaAvedra Alías y Miguel L. López-Guadalupe Muñoz, «Religiosidad popular e Ilustración. Las cofradías en Murcia», Mélanges de la Casa de Velázquez, XXXI-2 (1995), págs. 73-107, y «Cofradías y gremios en Navarra en la época de Carlos III», Hispania Sacra, 50 (1998), págs. 667-695.

142 M. ${ }^{a}$ del Prado Ravírez, Censo de Hermandades, Gremios y Cofradías del Conde de Aranda en la provincia de Ciudad Real, Ciudad Real, Diputación Provincial, 1986; Mantecón Movellán, Contrarreforma y religiosidad popular.

143 Esteban Mira Ceballos, Hermandades y cofradías en Badajoz y su partido a finales de la Edad Moderna, Badajoz, Junta de Extremadura, 2002; Fernando Manzano Ledesma, «La religiosidad colectiva de los zamoranos en la segunda mitad del siglo XviI: las cofradías del partido de Benavente en 1773», Brigecio: revista de estudios de Benavente y sus tierras, 15 (2005), págs. 145-168; Fernando Manzano Ledesma, «La religiosidad popular de los vallisoletanos en el siglo XVIII: el informe sobre las cofradías de Valladolid en 1773», Studia Historica. Historia Moderna, 29 (2007), págs. 387-425; Alfredo MarTín García, «Ilustración y religiosidad popular. El expediente de cofradías en la provincia de León (1770-1772)», Estudios humanísticos. Historia, 5 (2006), págs. 137-158; Margarita Torremocha Hernández, «Cofradías y devociones. Sociabilidad y religiosidad en Valladolid», en José L. Alonso Ponga y M. ${ }^{a}$ Pilar Panero García (eds.), 


\section{Restricciones a la religiosidad festiva}

El Expediente General de Cofradías ya expuesto no es más que la expresión de un desencuentro. El maridaje entre la Iglesia oficial y la religiosidad que representaban las cofradías - popular pero con un criterio ordenancista y de oficialidad - se disolvía a marchas forzadas. Lo que subyace a esta tensión dieciochesca, más que un avance de la secularización, es la floración de una nueva sensibilidad religiosa, que apostaba por lo personal, espiritual e incluso moral más que por lo colectivo, ritual y gestual ${ }^{144}$. Las cofradías se vieron en el centro del huracán y las restricciones les llegaron tanto desde el ámbito eclesiástico como desde la autoridad real y sus gobernantes, o más exactamente por instigación de los ministros que enarbolaban la bandera de las reformas.

Se ha puesto de manifiesto la larga trayectoria de supervisión de la vida cofrade por parte de la autoridad eclesiástica, a través de decretos episcopales y, en un marco general, mediante las resoluciones de concilios provinciales y sínodos diocesanos ${ }^{145}$. En general, velaban por la pureza del mensaje evangélico, tratando de atajar las adherencias profanas tan frecuentes en el universo de la religiosidad popular y de la mentalidad colectiva. Era expresión de su autoridad para discernir, aconsejar y exigir, y en ese sentido se implicaron sublimando lo esencial sobre lo accesorio, lo espiritual sobre lo material, lo moral sobre lo profano, lo necesario sobre lo desmedido. Esto ocurrió en realidad en todas las épocas, si bien en el siglo XVIII, merced a la indicada depuración de la piedad católica, sus efectos fueron más amplios en lo cuantitativo y en lo cualitativo. De hecho, casi todos los obispos dictaron decretos en ese sentido, de forma que costumbres tradicionales de las procesiones de Semana Santa ${ }^{146}$, de las romerías o de otras fiestas tradicionales, como las de la Cruz, San Juan o el ciclo de Navidad, se vieron afectadas ${ }^{147}$. Fue imposible desarraigar las costumbres de un

Gregorio Fernández: antropología, historia y estética en el barroco, Valladolid, Ayuntamiento de Valladolid, 2008, págs. 327-371; Maximiliano Barrio Gozalo, «Las cofradías de la diócesis de Segovia y el expediente general de 1771», en VV. AA., Minerva. Liturgia, fiesta y fraternidad en el Barroco español, Sepúlveda, 2008, págs. 21-43.

${ }_{144}$ Véase la contraposición en sendos trabajos de Teófanes EGIDo López, «La religiosidad de los ilustrados», y «La religiosidad de los españoles del siglo XVIII», en VV. AA, Carlos III y su tiempo, Madrid, 1990, vol. I, págs. 767-790. Las sugestivas tesis de M. Vovelle difícilmente pueden aplicarse a España: Michel Vovelle, Piété baroque et déschristianisation en Provence au XVIIIe siécle, Paris, Plon, 1973.

145 Arias de Saavedra Alías y López-Guadalupe Muñoz, «Auge y control de la religiosidad».

146 Joaquín Rodríguez Mateos «Las cofradías y las luces: decadencia y crisis de un fenómeno», en VV. AA., La Sevilla de las Luces, Sevilla, Ayuntamiento de Sevilla, 1991, págs. 132-147.

${ }_{147}$ Para el caso de Madrid, M. a José DEL Río, «Represión y control de fiestas y diversiones en el Madrid de Carlos III», en Equipo Madrid de Estudios Históricos, Carlos III, Madrid y la Ilustración, Madrid, 1988, págs. 299-329. En cuanto a cofradías romeras afectadas, Enrique Gómez MARTínEz, «Las cofradías de la 
pueblo - hubo prelados y eclesiásticos que ni se atrevieron-, pero por el momento se presentaba aquella religiosidad cofrade como algo pasado de moda y sus prácticas se fueron desplazando hacia el terreno de lo irracional — sin faltar el calificativo de fanático- o al menos de lo castizo-costumbrista ${ }^{148}$, aunque no faltaron en ellas mecanismos de resistencia.

Los ministros ilustrados abundaron en esa línea con más ahínco. En primer lugar, creían tener derecho para ello. Habría que insistir más en la relación entre regalismo y represión de la religiosidad popular ${ }^{149}$. Como punto de partida, al menos, reivindicaron el ámbito confraternal como una competencia propia del Estado, dado que los cofrades eran súbditos del rey, exigiendo en la real resolución de 1783 la necesidad de la aprobación regia para la subsistencia de hermandades y cofradías, algo que nunca se aplicó como medida general. Les preocupaba asimismo el exceso de gastos, que repercutía sobre las precarias economías familiares, el recurso a otras jurisdicciones para dirimir sus litigios y las implicaciones negativas que para el orden público podían tener determinadas concentraciones masivas propias de la piedad popular. Incluso trató de atajarse el destino de rentas a gastos «innecesarios» (ágapes o comilonas, cohetes, ornato excesivo, cultos desmesurados), prefiriendo destinarlas a usos de beneficencia, como se intentó tras esa tibia reforma de 1783. La desamortización de bienes de las cofradías, junto a los de patronatos, obras pías y capellanías, acometida por Miguel Cayetano Soler en $1798^{150}$, obedecía más a las urgencias económicas de la Hacienda que a esos criterios de racionalidad, pero bajo tan drástica decisión —nefasta desde luego para las hermandades mejor posicionadas - subyace un criterio general de inutilidad de estas corporaciones que los ilustrados se encargaron de alentar. La importancia de una opinión pú-

Virgen de la Cabeza y su suspensión en el reinado de Carlos III», Boletín del Instituto de Estudios Giennenses, 197 (2008), págs. 93-117.

148 La presencia cofrade en época contemporánea se rastrea, entre otras obras, en José ANDRÉs-GALLEGo, «Las Cofradías y Hermandades en la España Contemporánea», en VV. AA., Actas. Primer Congreso Nacional de Cofradías de Semana Santa, págs. 69-75, y Miguel L. López-Guadalupe Muñoz, «Las cofradías en la España del siglo XIX», XX Siglos, 25 (1995), págs. 43-56.

149 Diversos aspectos de la represión de fiestas en Miguel L. López-Guadalupe Muñoz, «La fiesta religiosa en la diócesis de Granada (1750-1825). Opinión, control y represión», Chronica Nova, 21 (1993-94), págs. 239-278; Miguel L. LópEZ-GuadaluPe Muñoz, «Control de la fiesta religiosa en la Granada de fines del siglo XVIII », en Alberto Romero Ferrer (coord.), Juego, Fiesta y Transgresión, 1750-1850, Cádiz, Universidad de Cádiz, 1995, págs. 293-308.

150 Poco estudiada desde la óptica cofrade, caben destacar los trabajos clásicos de Richard HerR, «Hacia el derrumbe del Antiguo Régimen: crisis fiscal y desamortización bajo Carlos IV », Moneda y Crédito, 118 (1971), págs. 37-100; Richard Herr, La Hacienda real y los cambios rurales en la España de finales del Antiguo Régimen, Madrid, Instituto de Estudios Fiscales, 1991. Una primera aproximación en M. a Amparo López Arandia, «Desamortización de cofradías en la ciudad de Jaén: fondos documentales», Memoria Ecclesiae, XXII (2003), págs. 267-282 
blica crítica, antes y durante las reformas, no hizo más que justificar el proceso represivo ${ }^{151}$.

Pero aquellos ilustrados fueron más allá de lo estrictamente temporal. Su visión del ámbito cofrade, y en general de la religiosidad del pueblo, era la de una «piedad mal entendida». Aquí aplicaron también la metáfora de la minoridad. De ese modo, la mentalidad religiosa popular quedaba anclada en una suerte de puerilidad y aun de futilidad, cuando no superstición, que era necesario y urgente erradicar. Los disciplinantes por las calles rechinaban tanto como la vestimenta de sombreros gachos y capas largas para la nueva imagen que pretendían ofrecer de España. En este sentido, las prácticas religiosas populares no es que fueran obsoletas — al contrario, estaban muy vivas y arraigadas en la realidad cotidiana - es que rayaban en lo ridículo, lo superficial y generalmente lo irreverente. En definitiva, en absoluto representaban un compromiso religioso personal en el sentido que los ilustrados difundían y, por tanto, también en su actuación hay un componente de renovación espiritual, íntimamente unida a sus objetivos de regeneración social y todo ello para mayor gloria de la Corona y del Estado ${ }^{152}$.

151 Inmaculada Arias de SaAvedra Alías y Miguel L. López-Guadalupe Muñoz, «Debate político y control estatal de las cofradías españolas en el siglo XVIII», Bulletin Hispanique, 99-2 (1997), págs. 423-435; Antonio Lara Ramos, «La lucha de la autoridad eclesiástica contra algunas prácticas de religiosidad en el obispado de Guadix (1750-1808)», en Antonio L. Cortés Peña y Miguel L. López-Guadalupe (eds.), Estudios sobre Iglesia y Sociedad en Andalucía en la Edad Moderna, págs. 341-354.

152 Virgilio Pinto Crespo, «Una reforma desde arriba: Iglesia y religiosidad», en Equipo Madrid de Estudios Históricos, Carlos III, Madrid y la Ilustración, Madrid, Siglo XXI, 1988, págs. 155-188. 